\title{
Competencia funcional, alcance y procedimiento en las autorizaciones judiciales de entrada para la ejecución forzosa de actos administrativos y en las autorizaciones judiciales para proteccion de la propiedad intelectual vulnerada desde servicios de la sociedad de la informacion
}

\section{José Luis Márquez Diéguez}

Letrado de la Gerencia de Urbanismo de Sevilla Profesor Asociado de la Universidad de Sevilla

SUMARIO: I. INTRODUCGIÓN. II. DETERMINACIÓN DE LA COMPETENCIA FUNCIONAL EN LAS AUTORIZACIONES JUDICIALES PARA LA EJEGUGIÓN FORZOSA DE ACTOS ADMINISTRATIVOS: 1.Estudio analítico de supuestos generales; 2. La excepcionalidad de los supuestos de ejecución de actos administrativos de interrupción de la prestación de servicios de la sociedad de la información o de retirada de contenidos que vulneren la propiedad intelectual. III. ALCANCE DE LA INTERVENGIÓN JUDICIAL Y PROCEDIMIENTO PARA SU EJERCICIO: 1. Objeto y límite de la intervención judicial: control limitado del juez para adecuarse a la precisa función de su intervención; 2. Procedimiento para el otorgamiento de autorización judicial en los supuestos generales; 3. Procedimiento para la concesión de autorización judicial en los casos de reacciones administrativas ante lesiones a la propiedad intelectual causadas a través de servicios de la sociedad de la información. IV. GONCLUSIONES.

RESUMEN:

Las Administraciones Públicas, cuando pretenden ejecutar de modo forzoso actos administrativos y para ello resulta necesario acceder al domicilio de los 
interesados, están legalmente obligadas con carácter general a solicitar autorización judicial de entrada. Estas autorizaciones judiciales presentan ciertas dificultades en cuanto a la determinación de qué concreto órgano judicial ostenta la competencia funcional para otorgarla en cada caso, cuál es el alcance de la intervención judicial en estos casos y qué procedimiento ha de seguirse para la tramitación de estas autorizaciones judiciales. Por otra parte, especial singularidad en esos mismos aspectos revisten las autorizaciones judiciales para la ejecución forzosa de actos administrativos destinados a proteger derechos de propiedad intelectual que eventualmente se puedan ver vulnerados a través de servicios de la sociedad de la información.

Palabras clave: autorización judicial, ejecución forzosa, actos administrativos, competencia funcional, protección de la propiedad intelectual, servicios de la sociedad de la información.

\section{ABSTRACT:}

Public administrations, when they seek to forcibly carry out administrative acts and for this purpose it is necessary to access to the domicile of the interested parties, are legally obliged generally to request a judicial authorization of entry. These judicial authorizations presented certain difficulties in the determination of which particular court holds the functional competence to grant it in each case, what is the scope of judicial intervention in such cases and which procedure has to be followed for the processing of these judicial authorizations. On the other hand, in those same aspects is special uniqueness of the judicial authorizations for the enforcement of administrative acts intended to protect intellectual property rights that may eventually be violated through the information society services.

Keywords: judicial authorization, enforcement, administrative acts, functional competence, intellectual property protection, the services of the information society.

\section{INTRODUCGIÓN}

En no pocas ocasiones, las Administraciones Públicas se ven en la obligación de ejecutar de modo forzoso numerosos actos administrativos que previamente han dictado ante la desatención de lo resuelto en los mismos por parte de los administrados a quienes se dirigen y quienes, consecuentemente, son los obligados prima facie a darles cumplimiento. 
El principio de autotutela ejecutiva garantiza a la Administración Pública, previo apercibimiento, la ejecución forzosa de sus propios actos. Este principio se halla reconocido con carácter general en los artículos 56, 57, 94 y 95 de la Ley 30/1992, de 26 de noviembre, de Régimen Jurídico de las Administraciones Públicas y del Procedimiento Administrativo Común (en adelante, LRJPAC), si bien el último de los preceptos citados excepciona los supuestos en que la Constitución o la Ley exijan la intervención de los Tribunales.

Es bastante frecuente que para la ejecución forzosa de esos actos administrativos resulte necesaria e inevitable, como única forma de llevarla a cabo, la entrada en domicilio y, a estos efectos, el artículo 96.3 LRJPAC dispone que si, para la ejecución forzosa de un acto administrativo, fuese necesario entrar en el domicilio del afectado, las Administraciones Públicas deberán obtener el consentimiento del mismo o, en su defecto, la oportuna autorización judicial, por exigencia del artículo $18.2 \mathrm{CE}^{1}$ como garantía de que la afección que se realice al derecho fundamental a la inviolabilidad del domicilio consagrado en el apartado 1 del mismo artículo 18 esté absolutamente justificada y resulte la mínima imprescindible, apreciadas ambas circunstancias por un órgano judicial (por todas, STG núm. 144/1987 [RTG 1987\144]). La Constitución Española de 1978 incorpora de esta forma la protección del domicilio que ya se encontraba contemplada en el artículo 12 de la Declaración Universal de Derechos Humanos de 1948, en el artículo 8.1 del Convenio Europeo de Derechos Humanos de 1950 y el artículo 17.1 del Pacto Internacional de Derechos Civiles y Políticos de 1966.

El alcance de los mencionados apartados 1 y 2 del artículo 18 de nuestra Carta Magna se definió perfectamente por el Tribunal Constitucional ya en Auto núm. 129/1990, de 26 de marzo (RTC 1990\129) que citaba sentencias anteriores del propio Tribunal Constitucional ${ }^{2}$.

${ }^{1}$ La STC de 30 de noviembre de 1992 (RTG \1992\211), reproduciendo otra anterior, es concluyente al afirmar que “.... también en las «entradas administrativas» es menester la autorización judicial prescrita por el art. 18.2 de la Constitución que no establece excepciones a la garantía procesal que introduce”.

${ }^{2}$ Esta STC reza así en su FD $3^{\circ}$ :

"En el enunciado del art. 18.2 de la Constitución ("El domicilio es inviolable. Ninguna entrada o registro podrá hacerse en él sin consentimiento de titular o resolución judicial, salvo caso de flagrante delito»), este Tribunal ha identificado dos reglas distintas: una primera regla de carácter genérico o principal, que define la inviolabilidad del domicilio, que constituye un auténtico derecho fundamental de la persona, establecida «para garantizar el ámbito de la privacidad de ésta dentro del espacio limitado que la propia persona elige y que tiene que caracterizarse por quedar exento o inmune a las invasiones o agresiones exteriores de otras personas o de la autoridad pública); otra segunda regla, aplicación concreta de la primera y, por ello, de más reducido contenido, que «establece un doble condicionamiento a la entrada y al registro, que consiste en el consentimiento del titular o en la resolución judiciab. La interdicción fundamental de este precepto es la del registro domiciliario, entendido 
Por otra parte, es importante hacer notar que el alcance espacial a que se refiere el artículo 8.6 LJCA no se limita al domicilio de las personas físicas, sino que se extiende a otros lugares en los que el acceso requiera igualmente el consentimiento de su titular ${ }^{3}$.

Efectuadas las anteriores precisiones, resulta evidente que la Administración conserva la potestad para ejecutar los actos administrativos con sus propios medios, pero el juez debe comprobar previamente que con el ejercicio de esta potestad no se lesionan derechos y libertades fundamentales, esencialmente el derecho fundamental a la inviolabilidad domiciliaria, por lo que al juez corresponde encontrar un adecuado equilibrio entre los derechos de los administrados que hayan de verse afectados (el ya repetido derecho a la inviolabilidad del domicilio) y la necesaria eficacia en la actuación de las AAPP cuando tutelan los intereses generales (STC de 15 de octubre de 1997). Se trata de un equilibrio consustancial al Estado de Derecho mismo, en el que, si bien las AAPP están investidas de potestades que las coloca en una posición de privilegio en sus relaciones jurídicas con los ciudadanos en razón de los superiores intereses generales que defienden, esas potestades no pueden tener un carácter omnímodo e incontrolado, sino que han de estar revestidas de suficientes ga-

como inquisición o pesquisa, para lo cual la entrada no es más que un trámite de carácter instrumental (STC 22/1984, fundamento jurídico $5 .^{\circ}$ ).

De las dos reglas expuestas, la segunda es la que directamente entra aqui en juego, y de su contenido interesa precisar que, salvo caso de flagrante delito, sólo dos títulos habilitan la entrada por la autoridad pública en domicilios particulares, el consentimiento del interesado o la autorización judicial y, asimismo, que de estos dos títulos el primero es más débil que el segundo, por cuanto no sólo en defecto de consentimiento del titular, sino también en contra de él puede la autoridad pública penetrar en el domicilio si está habilitada a tal efecto por una autorización judicial.

La inviolabilidad del domicilio, o sea, «el derecho de no penetración en el domicilio en contra de la voluntad del titular del mismo» protegida por el art. 18.2 de la CE, es así «un derecho relativo y limitado» en cuanto que la propia Constitución autoriza su restricción en supuestos contemplados por la Ley, aunque exige, en principio, una decisión judicial al respecto, salvo en los casos de "flagrante delito» (STC 199/1987 [RTC 1987\199], fundamento jurídico 9. '). Pues, como ha declarado reiteradamente este Tribunal, no existen derechos ilimitados y la restricción de un derecho fundamental tiene su fundamento, bien directamente en la Constitución o bien en el respeto de otros derechos constitucionales o bienes constitucionalmente protegidos (SSTC 11/1981 [RTC 1981 \11], fundamento juridico 7.; 2/1982 [RTC 1982 \2], fundamento jurídico 5. ; y 110/1984 [ RTC 1984\110], fundamento jurídico 5. \%), ....."

${ }^{3}$ Como muy bien razona la Sala de lo Contencioso-Administrativo del Tribunal Superior de Justicia de Galicia en el FD Primero de su sentencia de 18 de noviembre de 2010 (JUR 2011 41114 ):

"Sobre el domicilio recuerdan las Ss TC 22/1984, 69/1999 y 94/1999 que lo que la Constitución protege «es el domicilio en cuanto morada de las personas fisicas y reducto último de su intimidad personal y familian, esto es, el «espacio apto para desarrollar la vida privada» (STC 283/2000), ya que no todo local sobre cuyo acceso posee poder de disposición su titular debe ser considerado como domicilio a los fines de la protección que el artículo 18.2 de la CE garantiza (SsTC 149/1991 y 69/1999), pero sí se extiende la protección de la inviolabilidad domiciliaria, aunque con menor intensidad, a los espacios fisicos estrechamente vinculados con el ámbito de intimidad que sean indispensables para que las personas puedan desarrollar su actividad, profesional o privada, sin intromisiones (Ss TC 137/1985, 144/1987 y 64/1988)." 
rantías que impidan un exceso por parte de esas Administraciones en su ejercicio, una lesión ilegítima e innecesaria de derechos fundamentales y libertades públicas. Lo expresa de forma muy concisa y acertada el Tribunal Superior de Justicia de Andalucía, Sala de lo Contencioso-Administrativo de Granada, en su sentencia de 2 de septiembre de 2002 (RJCA 2002\1116).

Ello nos conduce a plantearnos tres cuestiones de esencial relevancia que constituirán el objeto principal del presente estudio: qué concreto órgano jurisdiccional ostenta la competencia funcional para otorgar en cada caso la autorización judicial de entrada para la ejecución forzosa de un acto administrativo, cuál es el alcance del control jurisdiccional sobre la entrada en domicilio por una Administración con ese fin específico y, por último, cuáles son los requisitos formales que han de respetarse para finalmente otorgar/denegar la autorización judicial interesada por una Administración Pública a los efectos señalados.

No obstante, también dedicaremos algunas notas al análisis del régimen jurídico excepcional que la Ley 2/2011, de 4 de marzo, de Economía Sostenible, y el Real Decreto 1889/2011, de 30 de diciembre, por el que se regula el funcionamiento de la Comisión de Propiedad Intelectual, han venido a establecer para las solicitudes de autorizaciones judiciales encaminadas a hacer posible la ejecución por la Administración de determinados actos en relación con los servicios de la sociedad de la información para salvaguarda de los derechos de propiedad intelectual.

Realizamos este estudio con la pretensión de tratar estos aspectos no desde una exclusiva perspectiva doctrinal, sino incorporando a nuestras reflexiones la experiencia práctica que nuestra labor profesional habitual nos aporta sobre estas cuestiones.

\footnotetext{
${ }^{4}$ En su FD Primero justifica que:

“....la Administración, al amparo de la llamada autotutela administrativa, puede ejecutar directamente sus propios actos, pero en la medida en que ello constituye un presupuesto inherente a las facultades exorbitantes de la Administración, ésta puede ser excepcionada por una Ley imponiendo la intervención de los Tribunales a la hora de ejecutar los actos administrativos en determinados supuestos. Por tal razón el artículo 95 de la Ley 30/1992, de 26 de noviembre, tras disponer que «las Administraciones Públicas, a través de sus órganos competentes en cada caso, podrán proceder, previo apercibimiento, a la ejecución forzosa de los actos administrativos», establece como excepciones al principio general "los supuestos en que se suspenda la ejecución de acuerdo con la Ley o cuando la Constitución o la Ley exijan la intervención de los Tribunales»; y, por su parte, la Ley 29/1998, de 13 de julio, reguladora de la Jurisdicción Contencioso-Administrativa, en cumplimiento de tal previsión, ha atribuido (art. 8.5) a los Juzgados de lo Contencioso-Administrativo la competencia para «autorizar la entrada en domicilios y restantes lugares cuyo acceso requiera el consentimiento de su titular, siempre que ello proceda para la ejecución forzosa de actos de la Administración Públicas, sin duda con el propósito de conciliar, a través de este medio procesal, el respeto al derecho fundamental a la inviolabilidad del domicilio consagrado en el artículo 18.2 de la Constitución, con el principio de ejecutoriedad de los actos administrativos."
} 


\section{DETERMINACIÓN DE LA COMPETENGIA FUNGIONAL EN LAS AUTORIZACIONES JUDICIALES PARA LA EJEGU- CIÓN FORZOSA DE ACTOS ADMINISTRATIVOS}

\section{Estudio analítico de supuestos generales.}

Aunque inicialmente pudiese parecer lo contrario, no está exenta de dificultades la determinación, en ausencia de consentimiento voluntario del administrado, de qué órgano judicial ostenta la competencia funcional para conocer de las solicitudes de autorizaciones judiciales de entrada que formulan las Administraciones Públicas para acceder al domicilio de los afectados al objeto de ejecutar de forma subsidiaria actos administrativos incumplidos previamente por los obligados y que, por no ser personalísimos, pueden ser ejecutados por otro sujeto distinto de los propios obligados, de conformidad con lo dispuesto en el artículo 98 LRJPAC.

El trámite judicial actualmente previsto en el artículo 8.6 de la Ley 29/1998, de 13 de julio, reguladora de la Jurisdicción Contencioso-Administrativa $^{5}$ (en lo sucesivo, LJCA) trae causa o antecedente inmediato de lo prevenido en el antiguo artículo 87.2 de la Ley Orgánica del Poder Judicial (apartado 2 que fue suprimido por el artículo único de la Ley Orgánica 6/1998, de 13 de julio, de reforma de la Ley Orgánica del Poder Fudicial). El contenido de uno y otro precepto viene a ser esencialmente el mismo, con la salvedad relativa al orden jurisdiccional y los órganos en que se residencia la competencia para conocer de este procedimiento, ahora reservada a la Jurisdicción Contencioso-Administrativa y específicamente a los Juzgados de lo Contencioso-Administrativo y antaño a la Jurisdicción Penal y, más en concreto, a los Juzgados de Instrucción. Además, a diferencia de lo que antes sucedía, la LJCA prevé expresamente la posibilidad de recurrir en apelación la resolución judicial que recaiga en este procedimiento [artículo 80.1.d)].

En una aproximación inicial, como decimos, pudiera parecernos fácil la determinación del órgano judicial con competencia funcional para conocer de las autorizaciones judiciales para la ejecución de actos administrativos, pero, como a continuación razonaremos, se trata solo de una falsa apariencia, ya que

\footnotetext{
${ }^{5}$ En la versión original de la Ley 29/1998 era el artículo 8.5, pasando a ser el artículo 8.6 tras la modificación de la misma operada por la Ley Orgánica 19/2003, de 23 de diciembre, de Modificación de la Ley Orgánica 6/1985, de 1 de julio, del Poder Judicial, pero que en su Disposición Adicional Decimocuarta también reforma varios preceptos de la Ley 29/1998, de 13 de julio, reguladora de la Jurisdicción Contencioso-administrativa.
} 
la solución de este problema no resulta tan sencilla como en un principio de forma apresurada pudiere intuirse.

Una primera dificultad que se nos plantea, no la mayor, es la de discernir la competencia territorial, ya que, podría surgir la duda de si es de aplicación la Regla Primera del artículo 14.1 LJCA $^{6}$, o si lo es la Regla Tercera del mismo artículo 14.1 $\mathrm{LJCA}^{7}$. Sin embargo, la propia finalidad de la autorización judicial de entrada que es tutelar la afección que se produce al derecho constitucional de inviolabilidad del domicilio nos lleva a decantarnos sin discusión por la aplicación de la Regla Tercera, ya que resulta evidente que para el mejor fin de la tutela que se persigue es absolutamente relevante la inmediatez del juez, la mayor facilidad para comprobar, incluso, in situ las circunstancias de ocupación del domicilio y valorar la idoneidad de la entrada y las condiciones en que, en atención a esas circunstancias apreciadas, debe realizarse la entrada.

De cualquier modo, habría sido bueno que se hubiese aprovechado la Ley 13/2009, de 3 de noviembre, de reforma de la legislación procesal para la implantación de la nueva Oficina Judicial, para haber completado esa Regla Tercera del artículo 14.1 LJCA con la mención expresa a las solicitudes de autorizaciones judiciales de entrada para ejecución de actos administrativos, por lo que de lege ferenda proponemos la siguiente redacción "La competencia corresponderá al órgano jurisdiccional en cuya circunscripción radiquen los inmuebles afectados cuando se impugnen planes de ordenación urbana y actuaciones urbanisticas, expropiatorias y, en general, las que comporten intervención administrativa en la propiedad privada, así como en los casos de solicitudes de autorizaciones para la entrada en domicilios y restantes lugares cuyo acceso requiera el consentimiento de su titular previstas en el artículo 8.6 de esta Ley."

Así, puesto que los artículos 91.2 de la Ley Orgánica del Poder Judicial ${ }^{8}$ (en adelante, LOPJ) y $8.6 \mathrm{LJCA}^{9}$ establecen coincidentemente que los Juzgados de

\footnotetext{
${ }^{6}$ Dispone que "Con carácter general, será competente el órgano jurisdiccional en cuya circunscripción tenga su sede el órgano que hubiere dictado la disposición o el acto originario impugnado."

${ }^{7}$ Establece que "La competencia corresponderá al órgano jurisdiccional en cuya circunscripción radiquen los inmuebles afectados cuando se impugnen planes de ordenación urbana y actuaciones urbanísticas, expropiatorias y, en general, las que comporten intervención administrativa en la propiedad privada."

8 "Corresponde también a los fuzgados de lo Contencioso-administrativo autorizar, mediante auto, la entrada en los domicilios y en los restantes edificios o lugares cuyo acceso requiera el consentimiento del titular, cuando ello proceda para la ejecución forzosa de actos de la Administración."

9 "Conocerán también los Fuzgados de lo Contencioso-Administrativo de las autorizaciones para la entrada en domicilios y restantes lugares cuyo acceso requiera el consentimiento de su titular, siempre que ello proceda para la ejecución forzosa de actos de la Administración pública."
} 
lo Contencioso-Administrativo conocerán de las autorizaciones judiciales para la entrada en domicilio y restantes lugares cuyo acceso requiera el consentimiento de su titular, siempre que ello proceda para la ejecución forzosa de actos de las Administraciones Públicas, esto podría llevarnos a pensar en un primer momento que, consecuentemente, en todos los casos el órgano funcionalmente competente para conocer de cada solicitud de autorización judicial de entrada que se formule por una Administración Pública para la ejecución subsidiaria de un acto administrativo será indefectiblemente el Juzgado de lo Contencioso-Administrativo al que por reparto le correspondiese ese asunto. Sin embargo, el artículo 7.1 LJCA viene, como a continuación estudiaremos, a hacer más complejo el análisis de esta cuestión al disponer que "Los órganos del orden jurisdiccional contencioso-administrativo que fueren competentes para conocer de un asunto lo serán también para todas sus incidencias y para hacer ejecutar las sentencias que dictaren en los términos señalados en el artículo 103.1.”

En la práctica se nos ofrece una triple casuística a la hora de determinar qué específico órgano del orden jurisdiccional contencioso-administrativo, sentado ya indiscutiblemente que es este orden jurisdiccional el competente para ello, ostenta la competencia funcional para conocer de cada concreta autorización judicial que solicite una Administración Pública para la ejecución forzosa de un acto administrativo, que habremos de resolver con fundamento en el juego de los preceptos que ya hemos citado y de algunos otros que más adelante señalaremos por la incidencia que tienen en esta cuestión.

Resulta necesario efectuar un análisis pormenorizado de cada uno de los tres supuestos posibles para tratar de llegar a una conclusión acerca de la correcta determinación de la competencia funcional en cada uno de ellos:

$\left.\mathbf{1}^{\mathbf{0}}\right)$ Formulación de una solicitud de autorización judicial de entrada en un domicilio para acceder al mismo al objeto de ejecutar forzosamente un acto administrativo que no ha sido objeto de impugnación ante la Jurisdicción Contencioso-Administrativa.

Este primer supuesto entendemos que es el de más fácil respuesta, ya que, al no existir previa impugnación ante la Jurisdicción Contenciosa del acto administrativo que se pretende ejecutar forzosamente, en este caso la competencia funcional viene determinada por la aplicación directa de lo dispuesto en el artículo 8.6 LJCA, de modo que, como decíamos al principio, el órgano competente para conocer de la autorización judicial de entrada es el Juzgado de lo ContenciosoAdministrativo a quien le haya sido atribuido el asunto de acuerdo con el turno de reparto, de conformidad con lo establecido en el artículo 17 de la misma LJCA. 
Se trata de una cuestión hoy pacífica, una vez derogado el antiguo artículo 87.2 LOPJ y modificado el artículo 91 de la misma gracias a la reforma de la LOPJ introducida por Ley Orgánica 6/1998, de 13 de julio, para hacer concordante la LOPJ con el artículo 8.5 (hoy artículo 8.6) de la Ley reguladora de la Jurisdicción Contencioso-Administrativa que se aprobó en aquella misma fecha (Ley 29/1998, de 13 de julio).

$2^{\circ}$ ) Solicitud de autorización judicial de entrada para la ejecución forzosa de un acto administrativo que en ese momento se encuentra impugnado ante la Jurisdicción Contencioso-Administrativa.

En este segundo caso, la solución para determinar la competencia funcional en el conocimiento de la autorización judicial de entrada interesada es diametralmente opuesta y resulta del tenor del antes transcrito artículo 7.1 JLCA, conforme al cual, por encontrarse previamente impugnado ante la Jurisdicción Contencioso-Administrativa el acto administrativo que se pretende ejecutar forzosamente y estar, por tanto, conociendo ya de dicho recurso contenciosoadministrativo un concreto Juzgado de lo Contencioso-Administrativo, es ese mismo Juzgado el que ostenta la competencia para conocer de la autorización judicial de entrada posteriormente solicitada. A este respecto, la doctrina del Tribunal Constitucional expresada, entre otras, en SSTC de 13 de octubre de 1998 (RTG 1998\199) y 22 de abril de 2002 [RTC 2002\92], tiene declarado que, mientras se está sustanciando un proceso contencioso-administrativo, el órgano competente para otorgar la autorización judicial de entrada para la ejecución forzosa del acto impugnado es el que está conociendo del recurso contencioso-administrativo.

Tal solución se justifica porque, atribuyendo el conocimiento de la autorización judicial al mismo órgano judicial a quien corresponde examinar la conformidad a derecho del acto administrativo ya impugnado y que se trata de ejecutar forzosamente, se garantiza el derecho a la tutela judicial efectiva consagrado en el artículo 24.1 CE que implica que los ciudadanos puedan acudir a los Tribunales para impugnar los actos de la Administración (artículos. 106.1 y 117.3 de nuestra Carta Magna) y obtener un pronunciamiento sobre la ejecutividad o la suspensión de los mismos. También por imperativo del art. 24.1 $\mathrm{CE}$, cuando el órgano judicial competente se pronuncie sobre la ejecutividad o suspensión a él sometida, su decisión debe llevarse a cabo, lo que impide que otros órganos del Estado, sean administrativos o sean del mismo o de otro orden jurisdiccional distinto, resuelvan sobre tal pretensión, interfiriendo de esa manera en el proceso judicial de que conoce el Tribunal competente y convirtiendo así en ilusoria e ineficaz la tutela que pudiera dispensar éste. Hasta que 
no se tome la decisión al respecto por el Juzgado competente, el acto no puede ser ejecutado por la Administración, porque en tal hipótesis ésta se habría convertido en Juez, pero tampoco cabe la ejecución por otro órgano judicial distinto, porque esta eventualidad impediría que aquel Tribunal, el competente, pudiera conceder eficazmente la tutela, tal y como le impone el derecho fundamental (SSTC núm. 199\1998, de 13 de octubre [RTC 1998\199] ${ }^{10} \mathrm{y}$ núm. 76\1992, de 14 de mayo [RTC 1992\76 ]) $)^{11}$.

Esta solicitud de autorización judicial de entrada se deberá tramitar como una cuestión incidental del procedimiento principal, sustanciándose en pieza separada y sin suspender el curso de los autos, tal y como establece el artículo 137 LJCA.

No obstante, queda una cuestión por resolver, cuál es el órgano de la jurisdicción contencioso-administrativa con competencia para conocer de una solicitud de autorización judicial de entrada cuando la impugnación del acto administrativo para cuya ejecución forzosa se interesa la autorización judicial de

${ }^{10}$ Esta sentencia concluye que:

"Por imperativo del art. 24.1 CE la prestación de la tutela judicial ha de ser efectiva y ello obliga a que, cuando el órgano judicial competente se pronuncie sobre la ejecutividad o suspensión a él sometida, su decisión pueda llevarla a cabo, lo que impide que otros órganos del Estado, sean administrativos o sean de otro orden jurisdiccional distinto, resuelvan previamente sobre tal pretensión, interfiriéndose de esa manera en el proceso judicial de que conoce el Tribunal competente y convirtiendo así en ilusoria e ineficaz la tutela que pudiera dispensar éste. Hasta que no se tome la decisión al respecto por el Tribunal competente, el acto no puede ser ejecutado por la Administración, porque en tal hipótesis ésta se habría convertido en Juez (STC 78/1996) pero tampoco cabe la ejecución por otro órgano judicial distinto porque esta eventualidad impediría que aquel Tribunal, el competente, pudiera conceder eficazmente la tutela tal y como le impone el derecho fundamental (STC 76/1992)."

${ }^{11}$ El Tribunal Superior de Justicia de Cataluña se hace eco de esta doctrina del TC en su sentencia de 28 de junio de 2000 (RJCA 2000\1851), poniéndola, además, en relación con la posibilidad de solicitud de la medida cautelar de suspensión en el procedimiento principal:

".....no cabe ignorar que la ejecutividad de los actos administrativos no sólo puede sino que debe desplegar sus consiguientes efectos, que no deben tampoco ser desconocidos en la perspectiva procesal, ante la posible solicitud de medidas cautelares con fundamento en el artículo 135 de nuestra Ley Jurisdiccional. La Administración, caso de ser preciso, puede solicitar la entrada en un domicilio para atender a la debida ejecución de sus pronunciamientos incluso pendiente el plazo para poder impugnarlos judicialmente, debiéndosele otorgar o denegar previo el enjuiciamiento correspondiente de todas las circunstancias valorables al efecto. Para el caso de existencia de un proceso jurisdiccional contencioso-administrativo nada imposibilita, siendo por el contrario sus ventajas claramente apreciables, que la Administración deduzca su solicitud de entrada ante el mismo órgano jurisdiccional que entiende del asunto de que se trate o de la suspensión solicitada por la parte afectada, de forma que el mismo órgano jurisdiccional competente para el enjuiciamiento del acto administrativo y la decisión sobre su suspensión cautelar pueda pronunciarse sobre la entrada solicitada para atender a la ejecutividad del acto, si ello fuese lo procedente, lo que no ocurriría en el caso de haberse acordado en sede jurisdiccional su suspensión cautelar, al no quedar el órgano que conoce del fondo del asunto o de su suspensión cautelar vinculado por lo decidido en sede de entrada a domicilio para ejecución de actos administrativos, ante la improcedencia de una entrada para la ejecución de un acto administrativo cuya ejecutividad hubiese sido cautelarmente suspendida." 
entrada se está sustanciando ante la Sala de lo Contencioso-Administrativo del Tribunal Superior de Justicia por ser asunto de su competencia, ya que el artículo 8.6 LJCA atribuye la competencia objetiva para conocer de las solicitudes de autorizaciones judiciales de entrada a los Juzgados de lo ContenciosoAdministrativo en tanto que la competencia objetiva para conocer de la impugnación del concreto acto administrativo que se pretende ejecutar forzosamente puede venirle atribuida a las Salas de lo Contencioso-Administrativo de los Tribunales Superiores de Justicia ex artículo 10.1 LJCA.

Si bien el tenor del artículo 7.1 LJCA podría llevar a concluir que es la Sala de lo Contencioso-Administrativo del correspondiente Tribunal Superior de Justicia quien ostenta en este peculiar supuesto la competencia objetiva y funcional, consideramos que la atribución a los Juzgados de lo Contencioso-Administrativo con carácter general de la competencia objetiva para conocer de las solicitudes de autorizaciones judiciales de entrada (artículo 8.6 LJCA) puesta en relación con lo establecido en el artículo 13.c) de la propia LJCA ${ }^{12}$, debe llevarnos a la conclusión de la atribución de la competencia para conocer de la autorización judicial de entrada también en este caso a un Juzgado de lo Contencioso-Administrativo y no a la Sala de lo Contencioso-Administrativo, aún cuando ésta última esté conociendo del procedimiento principal en el que se impugna el acto administrativo, por lo que, dado que el asunto no se está sustanciando ante ningún otro órgano unipersonal de esta Jurisdicción, el competente deberá ser nuevamente aquél Juzgado de lo Contencioso-Administrativo al que por reparto le corresponda la solicitud formulada ad hoc por la Administración autora del acto pendiente de ejecución forzosa, y ello, en primer lugar, por un puro sentido práctico, a fin de evitar conflictos como el que se expresa y resuelve en la sentencia del Tribunal Superior de Justicia de Cataluña de 28 de junio de 2000 a que antes nos hemos referido ${ }^{13}$. En el mismo sentido

\footnotetext{
12 "Salvo disposición expresa en contrario, la atribución de competencia por razón de la materia prevalece sobre la efectuada en razón del órgano administrativo autor del acto".

${ }^{13}$ En esta sentencia se razona que: "En el caso concreto el Ayuntamiento solicitó del Fuzgado de lo ContenciosoAdministrativo autorización de entrada en una finca al objeto de poder ejecutar de forma completa el Plan Especial de Ordenación de determinado solar, gestionado por el sistema de expropiación, restando únicamente el desalojo de la indicada finca, petición que se entiende perfectamente atendible, visto el interés público prevalente para la ejecución del planeamiento de que se trata, que no está supeditado a razones de orden temporal ni puede producir al administrado perjuicio irreparable alguno, por lo que habrá de estimarse el recurso interpuesto, ordenándose la concesión de la autorización de entrada a los indicados efectos, siempre a salvo los efectos de una posible suspensión cautelar en sede jurisdiccional de la resolución o resoluciones impugnadas. $Y$ es que en relación con la materia de que se trata existe no uno, sino varios procesos contencioso-administrativos seguidos en secciones distintas de este Tribunal Superior de fusticia de Cataluña, dos contra la aprobación de la relación de bienes y derechos afectados por la expropiación, y otros dos contra la resolución definitiva del Jurado Provincial de Expropiación, en ninguno de los cuales consta que se haya solicitado o concedido la suspensión cautelar de la resolución en cada caso im-
} 
se pronuncia la Sala de lo Contencioso-Administrativo en Granada del Tribunal Superior de Justicia de Andalucía en sentencia de 11 de marzo de 2002 (JUR 2002\139044) al resolver la apelación deducida contra Auto de un Juzgado de lo Contencioso-Administrativo de Almería que autorizó la entrada de la Autoridad Portuaria de Almería-Motril en un quiosco del muelle de Levante del Puerto de Almería para proceder al desahucio de sus ocupantes, ante la alegación de los ocupantes de nulidad de pleno derecho de la resolución jurisdiccional por infracción del principio de tutela judicial efectiva consagrado en el art. 24.1 de la Constitución, así como de lo dispuesto en el art. 238.1 LOPJ, al entender los apelantes que el Juzgado dictó su resolución con absoluta falta de competencia objetiva y funcional, al corresponder ésta a la Sala de lo Contencioso-Administrativo de Granada, que conocía ya del recurso principal interpuesto por la parte ${ }^{14}$.

Sin perjuicio de lo anterior, consideramos que existe un argumento más para decantarse por la competencia de los Juzgados de lo Contencioso-Administrativo en lugar de la Sala de lo Contencioso-Administrativo en este supuesto algo más excepcional de solicitud de autorización judicial de entrada para la ejecución forzosa de un acto administrativo que se encuentra impugnado ante la Jurisdicción Contencioso-Administrativa y de cuya impugnación está conociendo la Sala. Este motivo suplementario para abogar por la competencia de

pugnada. Disgregación del conocimiento de la materia de que se trata entre distintas secciones, sin que pueda afirmarse con rotundidad la preeminencia de uno sobre otro de los recursos contenciosos interpuestos, con la consecuencia de que cualquiera de ellos pudiese atraer la competencia para resolver sobre la autorización de entrada solicitada, que aconseja y permite en cualquier caso afirmar la competencia para conocer de la solicitud de autorización de entrada por parte del fuzgado de lo Contencioso-Administrativo, en evitación de conflictos mayores y distorsiones funcionales que pudieran incluso afectar gravemente intereses públicos y privados, conduciendo a situaciones sin retorno."

${ }^{14}$ Los razonamientos desgranados en $\operatorname{los} \mathrm{FJ} 2^{\circ}$ y $3^{\circ}$ de esta sentencia rezan del siguiente modo:

"SEGUNDO .- En su escrito de oposición al recurso de apelación, el Sr. Abogado del Estado hizo distinción entre la competencia para el conocimiento del recurso principal, en el que se discute la resolución sobre desahucio en bien de dominio público portuario -que corresponde a la Sala-y la competencia para el conocimiento de la autorización de entrada como requisito previo a la ejecución de aquella medida administrativa, que, en cuanto no suspendida por la Sala, corresponde al Juzgado de lo contencioso-administrativo, en atención a lo dispuesto en el art. 8.5 de la Ley de la furisdicción.

TERCERO .- Planteada la cuestión en tales términos, ha de dictarse resolución desestimatoria del recurso de apelación, para decretar la plena conformidad a derecho de la resolución jurisdiccional atacada.

$\Upsilon$ es que la dicción del art. 8.5 de la Ley de la Furisdicción «...conocerán también los Fuzgados de lo Contencioso-administrativo de las autorizaciones para entrada en domicilios y restantes lugares cuyo acceso requiera el consentimiento de su titular, siempre que ello proceda para la ejecución forzosa de actos de la Administración pública», no ofrece ningún género de dudas con respecto de la competencia para las autorizaciones de entrada, refiriéndola al correspondiente Fuzgado de lo contencioso-administrativo, habiendo de distinguirse, con toda evidencia, entre el objeto del recurso contencioso-administrativo principal -la procedencia o no de la resolución administrativa de desahucio-y la autorización de entrada al bien objeto de desahucio, de la competencia del Juzgado, como requisito previo para la ejecución del acto de desahucio administrativo, del que no se solicitó la suspensión, según alegación no contradicha de órgano administrativo demandado." 
los Juzgados gravita sobre lo dispuesto en el artículo 80.1.d) LJCA que declara susceptibles de apelación los Autos dictados por los Juzgados de lo Contencioso-Administrativo sobre las autorizaciones previstas en el artículo 8.6 de la misma norma, a lo que se añade que en el artículo 87.1 LJCA no se relacionan entre los Autos recurribles en casación los de igual clase dictados por las Salas de lo Contencioso-Administrativo de los Tribunales Superiores de Justicia, por lo que no cabe llegar a otra conclusión más que entender que son únicamente los Juzgados de lo Contencioso-Administrativo los competentes para conocer de las solicitudes de autorizaciones judiciales de entrada, ya que cualquier otra solución quebraría de forma evidente el principio de equidad, puesto que un mismo pronunciamiento, concesión o denegación de una autorización de entrada, se sustanciaría en única instancia o, por el contrario, en doble instancia, dependiendo de que el procedimiento principal se sustanciase ante la Sala o ante un Juzgado de lo Contencioso-Administrativo, cuando el objeto de la intervención judicial es exactamente la misma y, por consiguiente, las instancias judiciales de que se disponga deberán ser también exactamente las mismas.

No obstante, también existe alguna sentencia discrepante con este criterio, como la sentencia de la Sala de lo Contencioso-Administrativo del Tribunal Superior de Justicia de Madrid de 18 de noviembre de 1999 (RJCA 1999\4940) que estima el recurso de apelación deducido contra el Auto por el que un Juzgado de lo Contencioso-Administrativo había otorgado autorización judicial de entrada para demoler unas chabolas ${ }^{15}$.

$3^{\mathbf{o}}$ ) Formulación de una solicitud de autorización judicial de entrada para ejecutar subsidiariamente un acto administrativo que, si bien en su momento fue objeto de impugnación ante la Jurisdicción Contencioso-Administrativa, en dicho recurso contencioso-administrativo, que ya fue resuelto, ha recaído sentencia firme.

Este supuesto es el que presenta una mayor complejidad. Es obvio que entre los casos $2^{\circ}$ y $3^{\circ}$ existe una clara diferencia, ya que mientras en el $2^{\circ}$ caso el procedimiento contencioso-administrativo en el que se ha impugnado el acto administrativo está en curso, se está sustanciado aún, está vivo, en cambio, en el $3^{\text {er }}$ caso el procedimiento judicial ya ha concluido, ha fenecido, puesto que

${ }^{15} \mathrm{Al}$ considerar la referida Sala que, existiendo recursos contencioso-administrativos contra la orden de desalojo y demolición de las chabolas interpuestos ante esa Sala, "la Administración debió deducir ante ella sus solicitudes de entrada respecto de aquellas en que no tuviera constancia de haberse solicitado la suspensión del acto administrativo; de lo contrario, podría producirse un fraude del derecho de los recurrentes a obtener tutela judicial efectiva, o, cuando menos, desajustes entre lo dispuesto por los diferentes órganos judiciales intervinientes." 
ha recaído sentencia firme desestimatoria de la demanda, por lo que la solución acerca de la competencia funcional será también diferente en uno y otro caso.

En este $3^{\text {er }}$ caso, al existir previa sentencia firme y no estar pendente ya el recurso contencioso-administrativo, debemos descartar que la solicitud de autorización judicial de entrada pueda ser considerada una incidencia de dicho recurso contencioso, por lo que no cabrá tramitarlo como una cuestión incidental de aquél.

Bien es cierto que en este tercer supuesto también podría pensarse, desacertadamente a nuestro juicio, que, cuando se solicita la autorización judicial de entrada para la ejecución forzosa del acto, se trataría de ejecutar una sentencia, lo que en la misma lógica llevaría a concluir que habría de sustanciarse como un incidente de ejecución previsto en el artículo 109 LJCA. Este planteamiento llevado a sus últimas consecuencias conduciría a admitir que, conforme a lo dispuesto en el artículo 518 LEC, la acción de la Administración para ejecutar forzosamente el contenido del acto administrativo confirmado por sentencia firme habría caducado una vez transcurridos 5 años desde la firmeza de la sentencia. Sin embargo, no podemos mostrarnos de acuerdo con este planteamiento, ya que es evidente que no se trata de ejecutar la sentencia recaída en el recurso contencioso-administrativo, sino de ejecutar un acto administrativo confirmado judicialmente, puesto que, aplicando la doctrina emanada del Tribunal Constitucional a propósito del derogado artículo 87.2 LOPJ dada la identidad de contenido del artículo 8.6 LJCA respecto de la redacción originaria de aquél, el expediente judicial instado al socaire del mencionado artículo 8.6 LJCA es un procedimiento donde de lo que se trata es de apoderar a la Administración para realizar una determinada actuación en ejecución de sus propias resoluciones (ATC núm. 129/1990), la competencia del Juzgado en este procedimiento de autorización judicial de entrada reside estrictamente en un control previo de los requisitos formales del acto que se pretende ejecutar, acto que ha sido dictado por la Administración que goza del privilegio de autoejecución de sus propios actos administrativos que el Tribunal Constitucional ha declarado ajustado a derecho con fundamento en los artículos 103 y $140 \mathrm{CE}^{16}$ y que actualmente se encuentra regulado con carácter ge-

${ }^{16}$ SSTC núm. 22/1984, de 17 de febrero (RTG 1984\22) y núm. 199/1998, de 13 de octubre (RTC 1998\199).La segunda de ella nos enseña que:

"Reiteradamente hemos declarado que el privilegio de autotutela atribuido a la Administración Pública no es contrario a la Constitución, sino que engarza con el principio de eficacia enunciado en el art. 103 CE (SSTC 22/1984 [ RTC

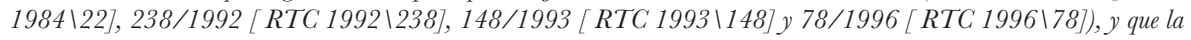


neral en el artículo 95 LRJPAC. En dicho precepto se establece que las Administraciones Públicas, a través de sus órganos competentes, podrán proceder, previo apercibimiento, a la ejecución forzosa de los actos administrativos. Entre los medios de ejecución forzosa previstos en los artículos 96 y ss. de dicha norma se encuentra, como decíamos al principio, la ejecución subsidiaria, aplicable cuando se trate de actos que, por no ser personalísimos, puedan ser realizados por sujeto distinto del obligado. Se trata, por tanto, de una cuestión completamente distinta de la ejecución de una sentencia, por lo que, consecuentemente, la sentencia firme confirmatoria del acto administrativo no constituye fundamento para la acción ejecutiva, conforme a lo dispuesto en el artículo 517 LEC, y, por tanto, no tratándose de la ejecución de una sentencia, debe descartarse la aplicación de lo previsto en el artículo 518 LEC.

Como muy acertadamente señala LAFUENTE BENACHES ${ }^{17}$, el Tribunal Supremo en sentencia de 30 de octubre de 1987 (RJCA 1987\7051) declara que, al conocer de una solicitud de autorización judicial de entrada, el juez no actúa en su función jurisdiccional típica del artículo 117.3 CE de "juzgar y hacer ejecutar lo juzgado", sino que lo hace para garantizar el derecho fundamental afectado por la ejecución forzosa administrativa, la inviolabilidad del domicilio. La función del juez se encuentra entre aquéllas que la Ley puede atribuirle en garantía de cualquier derecho, de conformidad con el artículo 117.4 $\mathrm{CE}^{18}$.

En este mismo sentido abunda el Tribunal Superior de Justicia de Madrid en su sentencia de 18 de noviembre de 1999 (RJCA 1999\1186) en la que se concluye que, de acuerdo con el esquema diseñado en el artículo 104 de la Ley de la Jurisdicción Contencioso-Administrativa, cuando se trata de una sentencia desestimatoria o declaratoria de la inadmisibilidad del recurso, no es potestad del Juzgado o Tribunal sentenciador acordar ejecución de ningún tipo, sino que la Administración recupera su potestad de autotutela, de autoejecución de sus actos, y es la única legitimada, una vez recaída sentencia desestimatoria o declaratoria de la inadmisibilidad del recurso contencioso, para dic-

ejecutividad de sus actos en términos generales y abstractos tampoco puede estimarse como incompatible con el art. $24.1 \mathrm{CE}$ (SSTC 66/1984 [ RTC 1984 \66], 341/1993 [RTC 19931341], 78/1996; AATC 265/1985 [ RTC $1985 \backslash 265$ AUTO], 458/1988 [ RTC $1988 \backslash 458$ AUTO], 930/1988 [ RTC 1988\930 AUTO], 1095/1988 [RTC 1988\1095 AUTO], 220/1991 [ RTC $1991 \backslash 220$ AUTO] y 116/1995 [ RTC 1995\116 AUTO]),..."

${ }^{17}$ LAFUENTE BENACHES, M.: La ejecución forzosa de los actos administrativos por la Administración Pública, Ed. Tecnos, Madrid, 1991, p. 86.

${ }^{18}$ Que dispone que "Los Juzgados y tribunales no ejercerán más funciones que las señaladas en el apartado anterior y las que expresamente les sean atribuidas por ley en garantía de cualquier derecho". 
tar un nuevo acto por el que disponga la ejecución del acto correspondiente ${ }^{19}$.Y también el Tribunal Superior de Justicia de Andalucía, Sala de lo Contencioso-Administrativo de Sevilla, en sentencia de 14 de mayo de 2009 (JUR $2009 \backslash 345261)^{20}$.

Sentado lo anterior, es obvio que, una vez que el recurso contencioso-administrativo interpuesto contra el acto administrativo se resuelve y la sentencia (desestimatoria o declaratoria de inadmisibilidad) recaída en el mismo deviene firme, no existen razones que impongan el conocimiento de la solicitud de autorización judicial de entrada por el mismo Juzgado que conoció del recurso contencioso contra el acto administrativo, ya que no existen, entonces, los riesgos para la tutela judicial efectiva que se tratan de evitar atribuyendo la competencia funcional a un mismo Juzgado, cuando el recurso está todavía pendente.

\footnotetext{
${ }^{19} \mathrm{El}$ razonamiento del $\mathrm{FJ} 4^{\circ}$ de esta sentencia es el que sigue:

"Debe precisarse (sin perjuicio de las particularidades que existen en ciertos procesos, fundamentalmente en los relativos a expropiación forzosa, dada su configuración subjetiva) que cuando la sentencia es desestimatoria, su parte dispositiva se limita a no anular una determinada actuación administrativa. Por otra parte, el hecho de desestimar un recurso no es igual a confirmar la actuación administrativa recurrida. No compete a los Tribunales de la jurisdicción "confirmar" o "revocar" actos administrativos. No existe una relación jerárquica entre aquéllos y las Administraciones públicas. No existe tutela de legalidad y mucho menos de oportunidad por parte de los Tribunales respecto de la Administración pública. Una sentencia desestimatoria se limita a no anular cierta actuación administrativa por considerar ésta ajustada a derecho. Pero esa actuación administrativa no tiene por qué convertirse, tras su enjuiciamiento por los Tribunales, muchas veces años después, en la única procedente o ajustada a derecho y obligatoria para la Administración. A diferencia de lo que sucede con las sentencias estimatorias, el acto administrativo que fue objeto de un recurso ulteriormente desestimado aún podría ser revisado por la Administración autora del mismo, cuando proceda y observando el procedimiento legal. No queda por tanto la Administración vinculada positivamente erga omnes por esa supuesta confirmación. Siendo una sentencia desestimatoria o declaratoria de la inadmisibilidad del recurso no tiene el tribunal nada que hacer ejecutar.

La Administración recupera su potestad de autotutela. No concurre por tanto el supuesto del art. 103.2 de la Ley Jurisdiccional. Es la Administración la que según el esquema del art. 104 de la Ley Jurisdiccional, una vez recaída la sentencia desestimatoria, está facultada para producir un nuevo acto administrativo (en el caso litigioso lo fue el acuerdo de 25.7.96) disponiendo, en su caso y en los términos que procedan en derecho, la ejecución del acto correspondiente, con observancia siempre de lo establecido en el art. 72 de la Ley Jurisdiccional de 1998.1, en lo que aquí interesa, aquel acto administrativo producido tras la resolución judicial no es otro que el previsto en el art. 8.5 de la ley jurisdiccional. Por ello la competencia para autorizar o no la entrada en domicilio, en cuanto se deriva de tal actuación administrativa, corresponde al Juzgado de lo contencioso-administrativo que la ejerció."

${ }^{20}$ En la que se afirma que:

“...... ésta es la esencia del proceso especial de autorización de entrada, suplir el consentimiento del titular en los supuestos negativos por la autorización judicial a través de un proceso especial. El indicado proceso especial es ajeno al enjuiciamiento de cuestiones de legalidad ordinaria, que deben ventilarse coherentemente en los procesos también ordinarios. No obstante, debe indicarse que no son de aplicación al supuesto presente los arts. 517 y 518 de la Ley de Enjuiciamiento Civil (Ley 1/2000), pues no se trata de ejecutar una acción fundada en sentencia y por ende de ejecutar una sentencia, sino que la sentencia de 18 de julio de 2003, dictada por el fuzgado de lo Contencioso Administrativo $n^{\circ} 6$ de Sevilla, lo que resuelve y declara es la confirmación de la legalidad de un acto administrativo de demolición, que por si mismo goza como todo acto administrativo, del privilegio de autotutela ejecutiva de los art. 94 y siguientes de la Ley 30/1992, de 26 de noviembre."
} 
De modo que podemos concluir que el órgano llamado a conocer de una solicitud de autorización judicial de entrada para ejecución de un acto administrativo, cuando existe ya sentencia firme desestimatoria o declaratoria de inadmisibilidad del recurso contencioso, es el Juzgado de lo Contencioso-Administrativo al que por reparto le corresponda tal solicitud, descartando tajantemente, como decimos, que la competencia funcional le venga atribuida al órgano de lo contencioso-administrativo que previamente conoció de la impugnación de ese acto administrativo, puesto que, resultando incontestable que en el mencionado trámite de autorización sólo habría de enjuiciarse la apariencia de legalidad del acto administrativo que se pretende ejecutar ${ }^{21}$, la firmeza de la resolución judicial recaída en el precedente procedimiento contencioso-administrativo de impugnación del acto administrativo convierte en innecesaria la atribución de la solicitud de autorización al mismo órgano judicial que conoció de éste, habida cuenta de que tal firmeza hace que en el trámite judicial de autorización de entrada no puedan plantearse cuestiones de legalidad ordinaria que ya fueron decididas con carácter de firme por el juzgador que conoció de la impugnación del acto administrativo.

En cualquier caso, si el órgano ante el que se hubiese solicitado la autorización judicial de entrada entiende que pudiese ser incompetente para conocer de ella, el mismo deberá ponérselo de manifiesto a las partes y al Ministerio Fiscal concediéndoles audiencia por plazo común de diez días conforme a lo dispuesto en el artículo 7.2 LJCA, para posteriormente declarar su incompetencia por Auto, remitiendo entonces las actuaciones al órgano de la Jurisdicción que estime competente para que ante él se tramite la solicitud de autorización judicial, de acuerdo con el artículo 7.3 LJCA.

\section{La excepcionalidad de los supuestos de ejecución de actos ad- ministrativos de interrupción de la prestación de servicios de la sociedad de la información o de retirada de contenidos que vulneren la propiedad intelectual.}

\footnotetext{
${ }^{21}$ Este es el limitado objeto que en cuanto a control de la legalidad del acto atribuye la doctrina del Tribunal Constitucional al Juez de lo Contencioso-Administrativo con ocasión del trámite de autorización judicial de entrada desde la ya lejana STC 144/1987, de 23 de septiembre (RTC 1987\144). El control de legalidad que ejerce el Juez en sede de autorización judicial de entrada es un control sólo superficial restringido a constatar la apariencia de legalidad del título ejecutivo invocado por la Administración para solicitar la entrada. Quedan excluidos, en consecuencia, de ese control motivos de fondo que habrán de articularse en el eventual recurso contencioso-administrativo que se formule contra el acto cuya ejecución se pretende.
} 
La Ley 2/2011, de 4 de marzo, de Economía Sostenible, a través de su Disposición Final Cuadragésima Tercera, ha modificado el artículo 8 de la Ley 34/2002 y el artículo 158 del Texto Refundido de la Ley de Propiedad Intelectual, aprobado por Real Decreto Legislativo 1/1996, de 12 de abril (en adelante, TRLPI). De acuerdo con estas modificaciones se introduce una nueva letra e) en el artículo 8.1 de la Ley 34/2002, de 11 de julio, de servicios de la sociedad de la información y de comercio electrónico que supone incluir "la salvaguarda de los derechos de propiedad intelectual" entre los principios que legitiman a los órganos competentes para su protección a adoptar las medidas necesarias para que se interrumpa su prestación o para retirar los datos que los vulneran, cuando un determinado servicio de la sociedad de la información atente o pueda atentar contra dicho principio ${ }^{22}$.

Para el ejercicio de esa nueva competencia referida a la salvaguarda de la propiedad intelectual, se modifica también, como hemos adelantado, el artículo 158 TRLPI para redenominar a la antigua Comisión Mediadora y Arbitral de la Propiedad Intelectual que pasa a llamarse Comisión de Propiedad Intelectual, a la vez que se le atribuye, junto a las que ya tenía de mediación y arbitraje en esta materia, las nuevas funciones de "la salvaguarda de los derechos de propiedad intelectual frente a su vulneración por los responsables de servicios de la sociedad de información en los términos previstos en los artículos o y concordantes de la Ley 34/2002, de 11 de julio, de servicios de la sociedad de la información y de comercio electrónico", y a tal fin se dota a la renovada Comisión de Propiedad Intelectual de dos secciones, la Primera encargada de sus tradicionales funciones de mediación y arbitraje y la Sección Segunda a la que se le encomienda velar en el ámbito de las competencias del Ministerio de Cultura por la salvaguarda de los derechos de propiedad intelectual frente a su vulneración por los responsables de servicios de la sociedad de información en los términos previstos en los artículos 8 y concordantes de la Ley 34/2002. El apartado 4 del referido artículo 158 TRLPI establece, tras la modificación operada en dicho precepto, que la ejecución de las medidas adoptadas por la Sección Segunda de la Comisión de Propiedad Intelectual exigirá la previa autorización judicial.

\footnotetext{
${ }^{22}$ Con anterioridad a esta modificación, esos principios legitimadores de la intervención eran exclusivamente los siguientes: a)La salvaguarda del orden público, la investigación penal, la seguridad pública y la defensa nacional; b)La protección de la salud pública o de las personas fisicas o jurídicas que tengan la condición de consumidores o usuarios, incluso cuando actúen como inversores; c) El respeto a la dignidad de la persona y al principio de no discriminación por motivos de raza, sexo, religión, opinión, nacionalidad, discapacidad o cualquier otra circunstancia personal o social; y d)La protección de la juventud y de la infancia.
} 
Asimismo, la Ley 2/2011 ha modificado el apartado 2 del artículo 8 de la Ley 34/2002 para posibilitar que la Comisión de Propiedad Intelectual puedan requerir a los prestadores de servicios de intermediación de la sociedad de la información para que faciliten los datos que permitan identificar a los responsables de servicios de la sociedad de la información que estén realizando conductas presuntamente vulneradoras de derechos de propiedad intelectual, previa intervención judicial autorizatoria de ello.

Como consecuencia de ello, la Ley 2/2011 se ha visto en la obligación de modificar igualmente los artículos 9 y 80.1.d) de la LJCA, así como introducir un nuevo artículo 122 bis en la misma, al objeto de:

- atribuir a los Juzgados Centrales de lo Contencioso-Administrativo, en una manifiesta excepción, tanto la autorización judicial a que se refiere el artículo 8.2 de la Ley 34/2002 como, en su caso, la posterior autorización judicial para la ejecución forzosa de los actos adoptados por la Sección Segunda de la Comisión de Propiedad Intelectual para la interrupción de la prestación de servicios de la sociedad de la información o la retirada de contenidos que vulneren la propiedad intelectual, en aplicación de la referida Ley 34/2002,

- establecer el procedimiento y plazos para la obtención de cada uno de esos dos tipos específicos de autorizaciones judiciales, y

- disponer que tales autorizaciones judiciales son también susceptibles de ser recurridas en apelación. De estas apelaciones conocerá la Sala de lo Contencioso-Administrativo de la Audiencia Nacional, de acuerdo con lo dispuesto en el artículo 11.2 LJCA.

\section{ALCANCE DE LA INTERVENCION JUDICIAL Y PROCEDI- MIENTO PARA SU EJERCICIO}

\section{Objeto y límite de la intervención judicial: control limitado del juez para adecuarse a la precisa función de su interven- ción.}

Según hemos expuesto, la intervención judicial en los casos de solicitudes de autorización judicial de entrada no se produce para reparar una supuesta lesión de un derecho o interés legítimo, sino que se produce como garantía de salvaguarda del derecho a la inviolabilidad del domicilio, tiene como específica función prevenir la vulneración de ese concreto derecho, es un mecanismo preventivo. De ahí que al Juez que conoce de la solicitud de autorización judi- 
cial de entrada para la ejecución forzosa de un acto administrativo no le corresponda enjuiciar la legalidad del acto que trata de ejecutarse subsidiariamente, sino que su intervención venga limitada a ponderar, con carácter previo a la entrada, que la restricción que sufre ese derecho resulta imprescindible para la defensa de unos intereses públicos prevalentes y que la misma es la estrictamente necesaria, que no es excesiva, ya que, en otro caso, supondría una vulneración no justificada del referido derecho constitucionalmente garantizado, un sacrificio desproporcionado. Como muy bien ha sintetizado el TC, entre otras en sentencia de 13 de octubre de 1998 (RTC 1998\199), la función de los jueces en estos casos es la de "garantes del derecho fundamental a la inviolabilidad del domicilio, lo cual significa que no es el fuez de la legalidad y de la ejecutividad del acto de la Administración, sino el Fuez de la legalidad de la entrada en domicilio".

Sin embargo, como la jurisprudencia viene refrendando de continuo, ello no significa que la intervención que el artículo 8.6 LJCA encomienda a los Juzgados de lo Contencioso-Administrativo responda a un automatismo formal, sino que, muy al contrario, ante una solicitud de autorización judicial de entrada para la ejecución forzosa de un acto administrativo a los mismos les compete el examen de la legalidad y legitimidad de la autorización judicial que se solicita, para lo que resulta imprescindible la constatación por el MagistradoJuez de la efectiva concurrencia de una serie de presupuestos y circunstancias legitimadoras y, asimismo, el establecimiento por parte del mismo de las cautelas que considere pertinentes en orden a evitar afecciones innecesarias o excesivas del derecho fundamental garantizado en el artículo 18.2 GE.

Así, la jurisprudencia constitucional ha ido definiendo el alcance de esa intervención judicial, sosteniendo que la misma debe circunscribirse a:

a) Constatar la concurrencia de los siguientes presupuestos:

- Que se encuentre perfectamente identificado e individualizado el titular del domicilio para el que se solicita la autorización de entrada.

A este respecto, es importante destacar que no debe confundirse la condición de propietario, que puede ser el obligado al cumplimiento de un acto administrativo, con la condición de titular del domicilio al que resulte preciso acceder para ejecutar de modo forzoso un acto administrativo, siendo así que uno y otro no tienen porqué coincidir necesariamente. Piénsese, por ejemplo, en el caso de la ejecución forzosa de una orden de ejecución de obras de seguridad o conservación en una vivienda ocupada en régimen de alquiler: el obligado a dar cumplimiento a la orden de ejecución es el pro- 
pietario de la vivienda, en cambio, el sujeto que deberá otorgar el consentimiento voluntario para que la Administración pueda acceder a la vivienda a fin de ejecutar subsidiariamente las obras será el inquilino, de modo que es exclusivamente la tutela del derecho de este segundo la que tiene como objeto el control judicial que se efectúa a través del trámite de la autorización judicial de entrada a que obliga el artículo 8.6 LJCA para el supuesto de que el titular del domicilio no haya concedido la autorización voluntaria, una vez requerido para ello, ya que el derecho a proteger es la inviolabilidad del domicilio y no el derecho de propiedad.

- Que el acto cuya ejecución forzosa se pretende tenga una apariencia de legalidad en sus aspectos más básicos.

En este particular la jurisprudencia ha definido restrictivamente, de una forma que hoy podemos considerar perfectamente acabada, cuales son los concretos aspectos del acto administrativo a ejecutar forzosamente que debe examinar el Juez de lo Contencioso con ocasión de una solicitud de autorización judicial de entrada para ello, señalando que le compete asegurarse de que no existan infracciones evidentes, esto es, graves y manifiestas, en el bien entendido de que este examen debe quedarse en la epidermis del acto, descartando la existencia de una vía de hecho para lo que es necesario que el juzgador confirme que los requisitos formales de competencia y procedimiento han sido respetados en sus aspectos más esenciales, que se ha efectuado la correcta individualización del inmueble y de los afectados, que el acto se ha dictado por el órgano competente en el ejercicio de sus facultades y tras la tramitación de un procedimiento con apariencia de legalidad. Asimismo, debe cerciorarse de que el acto es ejecutivo, que no ha sido suspendido administrativa o judicialmente.

- Que la entrada en el domicilio es necesaria, idónea y proporcionada para la ejecución forzosa del acto administrativo.

La entrada debe ser proporcionalmente ajustada al fin que se persigue, correspondiendo al juez de la legalidad de la autorización de entrada constatar que no existen otros medios menos gravosos que posibiliten la coexistencia de los intereses en conflicto.

- Que se ha solicitado el consentimiento voluntario al titular del domicilio y que el mismo no lo ha prestado, o bien, lo ha denegado expresamente.

Como más arriba hemos razonado, la autorización judicial de entrada lo es 
en defecto de consentimiento voluntario, por lo que la Administración debe acreditar documentalmente de forma fehaciente que ha intentado obtener el permiso voluntario para la entrada del titular del domicilio y que éste no lo ha prestado. Para ello, es necesario que la Administración en cuestión haya formulado un previo requerimiento formal al referido titular otorgándole un determinado plazo para que otorgue el consentimiento voluntario, siendo muy aconsejable, de acuerdo con el principio de seguridad jurídica, que en el mismo se le advierta claramente que en caso de no consentir de modo expreso la entrada en dicho plazo, se entenderá el mismo denegado y se procederá a interesar autorización judicial de entrada de los Juzgados de lo Contencioso-Administrativo. De este modo, denegado expresamente el consentimiento dentro de ese plazo o entendiéndolo denegado por silencio en el caso de que nada haya manifestado el titular del domicilio dentro del plazo conferido en el requerimiento practicado al efecto, la Administración se encontrará plenamente legitimada para solicitar la autorización judicial de entrada ante la ausencia de consentimiento voluntario, restando únicamente la misma como vía posible para la ejecución forzosa del acto.

b) Establecer las necesarias cautelas sobre el acto mismo de la entrada, precisando los aspectos temporales de la misma, de forma que no quede a la discrecionalidad unilateral de la Administración el tiempo de su duración, así como otras circunstancias de la entrada sobre las que por el órgano jurisdiccional se estime necesario o conveniente introducir precisiones o limitaciones.

No obstante, la misma jurisprudencia mantiene que las exigencias en cada caso dependerán de las circunstancias que concurran, por lo que los requisitos de detalle formulados a propósito de casos concretos pueden no resultar precisos en otros supuestos en los que las circunstancias sean diferentes (STC 69/1999, de 29 de abril [RTC \1999\69]). A título de ejemplo, es fácil concluir que no serán iguales las cautelas y restricciones temporales precisas cuando la entrada se va a producir en el domicilio particular de una familia que cuando se va a producir en un local en el que se ejerce una actividad de guardería infantil o de residencia de la tercera edad, o cuando los es en otro local en el que se desarrolla actividad de hotel, o, finalmente, en otro en el que radica un despacho profesional. A nadie se le escapa que las limitaciones de las franjas horarias en que puede accederse al lugar para la ejecución forzosa del acto, las restricciones en cuanto al número de personas que pueden permanecer a un tiempo en el lugar en cuestión a tal fin, o, incluso, la imposición justificada de la obligación de una más estricta identificación nominal de las personas que acceden en cada momento al inmueble, pueden resultar más intensas en unos ca- 
sos que en otros en atención a las circunstancias propias y singulares de cada uno de ellos.

El adecuado examen y ponderación de esas circunstancias y establecimiento de las adecuadas cautelas para la entrada constituyen la motivación de la resolución judicial en estos casos, como se concluye en el fundamento jurídico segundo de la STC 139/2004, de 13 de septiembre (RTG 2004\13923.

En cualquier caso, a lo dicho debe añadirse que el control jurisdiccional también se proyecta sobre el acto mismo de la entrada que deberá llevarse a efecto de tal modo que no se produzcan más limitaciones al derecho que consagra el artículo 18.2 de la Constitución que las estrictamente necesarias, por lo que, respecto a las condiciones a observar en el acto de la entrada en el domicilio u otro lugar dependiente del consentimiento de su titular, conviene poner de manifiesto que es menester tener en cuenta aquellos aspectos del Título VIII del Libro II de la LEGr que, por referirse al respeto a los derechos fundamentales de la persona, puedan resultar de aplicación tanto a una investigación criminal, como a la ejecución forzosa de un acto administrativo, siempre modulados en razón de la distinta naturaleza de una y otra.

Por lo que respecta específicamente a las autorizaciones judiciales previas necesarias para salvaguarda de derechos de propiedad intelectual vulnerados desde servicios de la sociedad de la información, el objeto de la intervención del Juez de lo Contencioso en estos procedimientos en igualmente limitado, puesto que, en el caso de la solicitud de autorización judicial para requerir al prestador de servicios de intermediación de la sociedad de la información la cesión de los datos que permitan la identificación del presunto responsable de esa violación de derechos, la intervención judicial se restringe a constatar, de una parte, que existen al menos indicios de una posible vulneración de derechos de propiedad intelectual que habrán de poder deducirse de los documentos y ficheros que deberá acompañar la Sección Segunda de la Comisión de Propiedad Intelectual con su solicitud de autorización, de otra, que efectivamente el presunto responsable del servicio en el que se está realizando esa actividad vulneradora de derechos no está aún suficientemente identificado, por lo que es imprescindible la autorización judicial

${ }^{23}$ En este FJ $2^{\circ}$ se justifica que “......, desde la perspectiva constitucional, la resolución judicial por la que se autoriza la entrada en un domicilio se encontrará debidamente motivada y, consecuentemente, cumplirá la función de garantía de la inviolabilidad del domicilio que le corresponde, si a través de ella puede comprobarse que se ha autorizado la entrada tras efectuar una ponderación de los distintos derechos e intereses que pueden verse afectados y adoptando las cautelas precisas para que la limitación del derecho fundamental que la misma implica se efectúe del modo menos restrictivo posible." 
solicitada a tal fin, y por último, de otra, que con ello no resultan afectados los derechos garantizados en el artículo 18, apartados 1 y 3 , de la Constitución, ya que en este último caso, el juez habría de denegar la autorización judicial; mientras que, en el caso de la solicitud de autorización judicial para la ejecución forzosa de las medidas de interrupción de la prestación de servicios de la sociedad de la información o de retirada de sus contenidos que infringen la propiedad intelectual, la intervención del juez se limita a comprobar, en primer lugar, que existe una previa resolución de la Comisión de Propiedad Intelectual que declara la vulneración de los derechos de propiedad intelectual y ordena las medidas de interrupción de la prestación de servicios de la sociedad de la información o de retirada de sus contenidos, en segundo lugar, que le ha sido debidamente notificada al responsable, en tercer lugar, que la misma no hubiera sido cumplida voluntariamente por el mismo en el plazo de 24 horas señalado en el artículo 22.3 de la Ley 34/2002, de 11 de julio, de servicios de la sociedad de la información y de comercio electrónico y, en cuarto lugar, que la ejecución es proporcionada para proteger derechos garantizados en el artículo 20 de la Constitución que han resultado vulnerados.

\section{Procedimiento para el otorgamiento de autorización judicial en los supuestos generales.}

En los casos de autorizaciones judiciales de entrada no cabe duda de que la intervención judicial con el alcance antes señalado debe articularse a través de un procedimiento que, respetando las garantías procesales que exige la tutela del derecho fundamental a la inviolabilidad del domicilio, resulte lo suficientemente breve y ágil como para no provocar una demora excesiva e injustificada en la ejecución forzosa del acto administrativo, cuando en muchas ocasiones el interés general demanda una pronta ejecución. Esa intervención judicial debe, pues, encauzarse a través de un procedimiento de carácter sumario. Sin embargo, la LJCA no establece el procedimiento a través del cual debe ejercitarse esa intervención judicial en garantía del derecho a la inviolabilidad del domicilio.

No debemos dejar de poner de manifiesto la oportunidad que se ha dejado pasar para haber regulado específicamente el procedimiento especial de tramitación de las autorizaciones judiciales de entrada en domicilio para la ejecución forzosa de actos administrativos, primero en la Ley 2/2011, de 4 de marzo, de Economía Sostenible, en la que, en cambio, sí se ha establecido de forma singularizada un procedimiento sumarísimo para la ejecución forzosa de los actos de la administración dirigidos a salvaguardar los derechos de propiedad intelectual cuando estos están siendo vulnerados a través de los ser- 
vicios de la sociedad de la información, y después en la Ley 37/2011, de 10 de octubre, de medidas de agilización procesal.

Aún cuando, como decimos, no existe un procedimiento legalmente previsto para encauzar las peticiones de autorizaciones judiciales de entrada para ejecutar actos administrativos, sí que es posible establecer un conjunto de reglas que, como veremos, necesariamente han de respetarse en su tramitación.

A continuación, estudiaremos con detenimiento la forma de iniciación de este procedimiento, la audiencia a los interesados, la forma y contenido de la resolución judicial y los recursos procedentes contra la misma.

\section{A. Iniciación.}

El procedimiento se iniciará con solicitud de la Administración autora del acto que se pretende ejecutar de modo forzoso y a cuyo fin se interesa la autorización judicial de entrada. En la misma deberán identificarse con claridad:

a) el acto administrativo que se pretende ejecutar de modo forzoso,

b) el órgano autor del mismo,

c) el obligado a la ejecución del acto,

d) el inmueble, o dependencias del mismo, en que debe producirse la entrada para la ejecución forzosa,

e) el titular de dicho domicilio o lugar asimilado.

Además, resulta imprescindible que la Administración solicitante haga constar expresamente que el acto administrativo que se va a ejecutar forzosamente, no se encuentra suspendido administrativa o judicialmente, ya que, obviamente, de estar suspendido el acto, la autorización judicial habría de ser denegada de plano.

Del mismo modo, en la solicitud debe comunicarse si el acto administrativo está siendo o ha sido objeto de un recurso contencioso-administrativo, dada la relevancia de esta cuestión, a la que antes me he referido, a efectos de determinar el órgano judicial funcionalmente competente en tales casos para conocer y decidir sobre la solicitud de autorización judicial de entrada con la finalidad de evitar una lesión en la tutela judicial efectiva.

Finalmente, debe especificarse si la autorización de entrada se solicita para el acceso, no sólo del personal del correspondiente Servicio competente para la ejecución del acto de la Administración solicitante y, en su caso, de los ope- 
rarios y técnicos de la empresa contratada a los efectos de realizar las operaciones materiales que requiera la ejecución del concreto acto administrativo, sino también para el acceso de los Cuerpos y Fuerzas de Seguridad del Estado para el caso de que sea necesaria la compulsión sobre las personas en el supuesto de que se produzca resistencia a la ejecución forzosa pretendida.

Esta solicitud deberá ir acompañada de la documental que acredite la concurrencia de los presupuestos preceptivos para que pueda ser otorgada la autorización, es decir, deberán aportarse los documentos que prueben:

a) la condición del obligado a la ejecución del acto,

b) haberse dictado el acto administrativo por órgano administrativo en apariencia competente,

c) haberse notificado el acto al legalmente obligado (o, la publicación edictal, conforme a lo dispuesto en el articulo 59.5 LRJPAG),

d) el incumplimiento del obligado,

e) el previo requerimiento de autorización voluntaria de entrada al titular del domicilio o lugar asimilado, y la ausencia del consentimiento voluntario requerido en el plazo otorgado por la Administración a tal efecto o su denegación expresa.

Una vez presentada, la solicitud deberá ser examinada por el titular del órgano judicial y, si reúne los mencionados requisitos, el mismo habrá de acordar que se forme el correspondiente expediente para tramitar la solicitud, y acordar, con las precisiones y excepciones que a continuación diremos, el otorgamiento de un plazo de audiencia a los ocupantes del domicilio para el que se ha interesado la autorización judicial de entrada, ya que los principios de celeridad y economía procesal imponen que ambos trámites se impulsen simultáneamente en una misma resolución judicial.

La intervención del Juez de lo Contencioso-Administrativo en estos casos viene impuesta por la necesidad de comprobar la certeza de la necesidad, justificación y proporcionalidad de la afección del derecho fundamental de inviolabilidad del domicilio como reducto de la intimidad personal y familiar, y velar porque el mismo se vea menoscabado en la menor medida posible. De ahí que, siendo imprescindible la ponderación individualizada de las circunstancias concurrentes en cada caso concreto por el juez, incluida la proporcionalidad del medio (la necesidad de la entrada misma), neguemos la posibilidad de deducir, y subsiguientemente resolver, solicitudes de autorizaciones de entrada acumuladas, ya que ello indudablemente devendría en una inadecuada protección del mencionado derecho fundamental, salvo cuando se trate de la en- 
trada en varias viviendas de una misma edificación para la ejecución forzosa de un único acto administrativo.

\section{B. Audiencia.}

Los Juzgados y Tribunales no se pronuncian de modo uniforme acerca de la necesidad o innecesariedad de conceder audiencia con carácter previo al dictado del Auto que resuelva la solicitud de autorización judicial de entrada para la ejecución forzosa de un acto administrativo. Así, por ejemplo, el Tribunal Superior de Justicia de Andalucía en sentencia de 31 de marzo de 2000 estableció la necesidad de dar audiencia a los afectados al tratarse de una exigencia consustancial a las actuaciones procesales. En cambio, la Sala de la Contencioso-Administrativo del Tribunal Superior de Justicia de Cataluña, en sentencias de 2 de julio de 1999 y 30 de abril de 2002, considera que la falta de audiencia previa no vicia de nulidad la autorización de entrada otorgada por el Juez de lo Contencioso-Administrativo y, del mismo modo, el propio Tribunal Superior de Justicia de Andalucía, Granada (Sala de lo Contencioso-Administrativo, Sección $1^{\text {a }}$ ) en sentencia de 11 de marzo de 2002 (JUR $2002 \backslash 139044)^{24 .}$

En todo caso, aún cuando la LJCA no se pronuncia sobre la necesidad o no de dar audiencia al interesado en este procedimiento, a nuestro juicio, no cabe duda que, si bien pueden existir excepciones, lo cierto es que con carácter general, este procedimiento debe obedecer al principio de contradicción y, consecuentemente, que en el curso del mismo, tras la admisión de la solicitud de autorización judicial formulada por la Administración, el órgano judicial debe conceder audiencia a los afectados en relación con la pretensión ejercitada, a fin de que aleguen lo que tengan por conveniente en defensa de su derecho, si bien ha de quedar claro que las únicas alegaciones que podrían tener efecto obstativo al otorgamiento de la autorización judicial de entrada serían aquellas que pusiesen de manifiesto y acreditasen la ausencia de algunos de los presupuestos de obligado control y apreciación judicial con ocasión de esta intervención que hemos reseñado sintéticamente en el precedente apartado $A$. Cualesquiera otras alegaciones como pueden ser las referidas a cuestiones de fon-

\footnotetext{
${ }^{24}$ Que concluye lo siguiente:

"Sin que, en fin, haya lugar a atenderse el alegato del apelante de que no fue oído en el curso de la sustanciación de la autorización de entrada, pues es lo cierto que tal como ya se dijo en sentencia de esta Sala de 17 de septiembre de 2.001 «...la competencia para la autorización de entrada está conferida al titular del órgano jurisdiccional respectivo, sin necesidad de someterse a los trámites de un procedimiento específicamente diseñado al efecto, bastando con el examen y critica de la propia resolución administrativa, que ha de representar tanto como la ejecución forzosa de un acto de la Administración pública afectada»".
} 
do sobre el acto administrativo que se trata de ejecutar forzosamente son ajenas a esta específica intervención judicial y, por tanto, no serán acogibles en este procedimiento, ya que las mismas sólo pueden ser opuestas en el correspondiente recurso contencioso-administrativo contra aquel acto administrativo, pero no con ocasión de la solicitud de la autorización judicial de entrada para su ejecución forzosa en que el control judicial tiene una finalidad exclusiva de salvaguarda del derecho a la inviolabilidad del domicilio.

Discrepamos de quienes mantienen que uno de los supuestos en que debería de prescindirse de la audiencia a los interesados en el procedimiento de autorización judicial de entrada por la imposibilidad de cumplir con esta premisa por razones de urgencia es el de un edificio en situación de ruina inminente que exija un desalojo inmediato de sus ocupantes, ya que en este caso de extrema urgencia con riesgo para las personas, lo procedente no es que la Administración solicite la autorización judicial de entrada y el órgano judicial prescinda del trámite de audiencia a los interesados para acelerar su concesión, sino que es un caso expresamente previsto en el artículo 21.3 de la Ley Orgánica 1/1992, de 21 de febrero, sobre Protección de la Seguridad Ciudadana ${ }^{25}$, que legitima a la Administración para acometer todas las medidas de seguridad necesarias, incluido el desalojo de los ocupantes, prescindiendo de la solicitud de autorización judicial de entrada, con el sólo requisito de remitir posteriormente al Juzgado de lo Contencioso-Administrativo el acta o atestado que se levante de la actuación.

\section{G. Resolución.}

De acuerdo con lo dispuesto en el artículo 91.2 LOPJ, el procedimiento iniciado con la solicitud de autorización judicial de entrada se resuelve por Auto.

Ya hemos expuesto que la intervención del Magistrado-Juez en este tipo de procedimientos es de cognición limitada conforme se infiere de la jurispruden-

\footnotetext{
${ }^{25}$ El artículo 21 de la Ley Orgánica 1/1992, de 21 de febrero, sobre Protección de la Seguridad Ciudadana, dispone:

"1. Los agentes de las Fuerzas y Cuerpos de Seguridad solo podrán proceder a la entrada y registro en domicilio en los casos permitidos por la Constitución y en los términos que fijen las Leyes.

2. (E1 apartado 2 fue declarado inconstitucional y nulo por Sentencia del Tribunal Constitucional 341/1993, de 18 de noviembre).

3. Será causa legítima suficiente para la entrada en domicilio la necesidad de evitar daños inminentes y graves a las personas y a las cosas, en supuestos de catástrofe, calamidad, ruina inminente u otros semejantes de extrema y urgente necesidad.

En tales supuestos, y para la entrada en edificios ocupados por organismos oficiales o entidades públicas, no será preciso el consentimiento de la autoridad o funcionario que los tuviere a su cargo.

4. Cuando por las causas previstas en el presente artículo las Fuerzas y Cuerpos de Seguridad entrasen en un domicilio, remitirán sin dilación el acta o atestado que redactaren a la autoridad judicial competente."
} 
cia constitucional, estando restringida a la individualización del sujeto que debe soportar la entrada para la ejecución forzosa del acto, verificar la apariencia de legalidad de dicho acto a fin de evitar que se produzcan intromisiones arbitrarias en el domicilio o lugares asimilados a estos efectos, asegurarse de que la ejecución forzosa del acto requiere necesariamente la entrada y, finalmente, garantizar que la irrupción en el domicilio o esos otros lugares asimilados se produzca sin más limitaciones al derecho fundamental de la inviolabilidad del domicilio que las que resulten absolutamente imprescindibles e inevitables para la ejecución forzosa del acto.

El Auto que autoriza la entrada domiciliaria necesariamente ha de identificar con precisión la vivienda en la que se consiente la entrada forzosa, así como el titular de dicho domicilio. Además, debe contener, como forma de exteriorización del adecuado y efectivo ejercicio del control judicial que corresponde efectuar en estos asuntos, una motivación expresa que es necesario que escape a estereotipos y fórmulas genéricas, poniendo de manifiesto a las partes que se ha efectuado un singularizado examen del concreto caso, de sus presupuestos y circunstancias, así como una correcta ponderación de los derechos e intereses en conflicto y, por último, que se autoriza la entrada del modo menos gravoso o restrictivo del derecho a la inviolabilidad del domicilio.

Este Auto debe notificarse al afectado o, en su defecto, imponérsele en el propio Auto la obligación a la Administración de hacerle entrega de testimonio del mismo al afectado en el momento de efectuar la entrada domiciliaria para la ejecución forzosa del acto, testimonio que, en ese caso, lógicamente deberá acompañarse con la notificación del Auto que se le haga a la Administración solicitante de la autorización.

Aunque el Auto autorizando la entrada para la ejecución forzosa de un acto administrativo no equivale al Auto del Juez Instructor que ordena en el seno de un proceso penal la entrada y registro, sin embargo, en la medida en que aquella resolución judicial también restringe el derecho a la inviolabilidad domiciliaria debe someterse a un plazo de caducidad, que el juez autorizante debe fijar a su arbitrio, si bien deberá hacerlo siempre estableciendo un plazo suficientemente amplio (de entre dos y tres meses con carácter general, nos atrevemos a apuntar con fundamento en nuestra experiencia profesional en esta clase de asuntos), ya que no puede desconocerse que al tratarse de Administraciones Públicas todas sus actuaciones deben producirse a través de procedimientos administrativos, lo que indudablemente requiere que dispongan del tiempo necesario para tramitarlos, y, siendo habitual que en muchas ocasiones resulte preciso realizar la contratación de una empresa para ejecutar las obras 
u otros trabajos u operaciones materiales propias de la ejecución forzosa de un acto (por ejemplo, en supuestos de desalojos y traslados de enseres, de ejecución de obras de seguridad o de conservación, o en los casos de obras de restitución en procedimientos de protección de la legalidad urbanísticas), aprobar el correspondiente proyecto técnico, contratar igualmente a los directores técnicos y notificar anticipadamente a los interesados de la fecha en que se producirá la entrada forzosa. No obstante, cuando la autorización judicial de entrada se conceda con un plazo de eficacia escaso, siempre cabrá la posibilidad de que la Administración solicite motivadamente una ampliación de ese plazo inicial que con seguridad el/la Magistrado-Juez competente no tendrá inconveniente en otorgar cuando resulte acreditada su necesidad.

La Administración, una vez obtenida la autorización judicial de entrada, deberá dictar un nuevo acto acordando la ejecución forzosa con señalamiento de día y hora para ello, que deberá notificar tanto al sujeto obligado por el acto administrativo como al titular del domicilio al que se va a acceder para la ejecución forzosa haciendo uso de la autorización judicial de entrada, sujetos no siempre coincidentes. Por supuesto, en la entrada deberán evitarse actuaciones ajenas a su objeto, adoptándose, llegado el caso, las precauciones necesarias para no comprometer la reputación de los moradores y respetar sus secretos e intimidades.

Realizada la entrada, el órgano administrativo autorizado deberá dar cuenta al Juzgado que otorgó la autorización de entrada de haberla realizado y de cualquier incidencia ocurrida durante la misma.

D. Recursos.

Contra el Auto que concede o deniega una autorización judicial de entrada en domicilio cabe la interposición de recurso de apelación conforme a lo dispuesto en el artículo 80.1.d) LJCA.

Este recurso de apelación es admisible en un solo efecto, por lo que, dado que sólo tiene efectos devolutivos, la interposición de la apelación no conllevará en ningún caso la suspensión de la autorización judicial de entrada otorgada, y, por tanto, la Administración podrá proceder a la ejecución forzosa del acto haciendo legítimo uso de la misma.

Una vez firme la resolución judicial, el/la Magistrado-Juez acordará el archivo de las actuaciones con devolución, en su caso, del expediente administrativo que fue remitido en su día al Centro de procedencia. 


\section{Procedimiento para la concesión de autorización judicial en los casos de reacciones administrativas ante lesiones a la pro- piedad intelectual causadas a través de servicios de la socie- dad de la información.}

Como hemos anticipado, la Disposición Final Cuadragésima Tercera de la Ley 2/2011, de 4 de marzo, de Economía Sostenible, modifica el artículo 9 LJCA numerando su contenido anterior como apartado 1 y añadiendo un nuevo apartado 2 en el que se atribuye a los Juzgados Centrales de lo ContenciosoAdministrativo la competencia tanto para la autorización a que se refiere el artículo 8.2 de la Ley 34/2002 como para autorizar la ejecución forzosa de los actos dictados por la Sección Segunda de la Comisión de Propiedad Intelectual para que se interrumpa la prestación de servicios de la sociedad de la información o para que se retiren contenidos que vulneren la propiedad intelectual, en aplicación de la citada Ley 34/2002, de 11 de julio, de servicios de la sociedad de la información y de comercio electrónico.

Después de ello, la misma Disposición Final Cuadragésima Tercera, en su apartado Siete, introduce un nuevo artículo 122 bis en la LJCA, en cuyo ${ }^{\circ} 1$ se establece el procedimiento para obtener la autorización judicial a que se refiere el artículo 8.2 de la Ley $34 / 2002^{26}$, y seguidamente en su n ${ }^{\circ} 2$ se contempla otro procedimiento distinto para obtener la autorización judicial preceptiva para la ejecución forzosa de las medidas de interrupción de la prestación de servicios de la sociedad de la información o de retirada de los contenidos que vulneren la propiedad intelectual adoptadas por la Sección Segunda de la Comisión de Propiedad Intelectual en aplicación también de la Ley 34/2002.

Conviene poner de manifiesto que este novedoso artículo 122 bis se inserta sistemáticamente en la Ley 29/1998 en el Capítulo I. PROCEDIMIENTO PA-

\footnotetext{
${ }^{26}$ El apartado segundo del artículo 8 de la Ley 34/2002, de 11 de julio, de servicios de la sociedad de la información y de comercio electrónico, también ha sido introducido ex novo por la Ley 2/2011, de 4 de marzo, de Economía Sostenible, con renumeración correlativa de los anteriores apartados 2, 3, 4 y 5 de dicho artículo 8. El tenor literal de ese nuevo $\mathrm{n}^{\circ} 2$ del artículo 8 es el siguiente:

"2. Los órganos competentes para la adopción de las medidas a que se refiere el apartado anterior, con el objeto de identificar al responsable del servicio de la sociedad de la información que está realizando la conducta presuntamente vulneradora, podrán requerir a los prestadores de servicios de la sociedad de la información la cesión de los datos que permitan tal identificación a fin de que pueda comparecer en el procedimiento. Tal requerimiento exigirá la previa autorización judicial de acuerdo con lo previsto en el apartado primero del artículo 122 bis de la Ley reguladora de la Jurisdicción contencioso-administrativa. Una vez obtenida la autorización, los prestadores estarán obligados a facilitar los datos necesarios para llevar a cabo la identificación."
} 
RA LA PROTECCIÓN DE LOS DERECHOS FUNDAMENTALES DE LA PERSONA del TÍTULO V. PROCEDIMIENTOS ESPECIALES, si bien, como hemos mencionado, realmente regula dos procedimientos específicos para la obtención de autorización judicial previa en los supuestos establecidos en la Ley 34/2002 para salvaguarda de derechos de propiedad intelectual ante agresiones efectuadas a través de servicios de la sociedad de la información, tras su reforma por la Ley 2/2011, de 4 de marzo, de Economía Sostenible.

Este régimen jurídico se ha visto completado por el Real Decreto 1889/2011, de 30 de diciembre, por el que se regula el funcionamiento de la Comisión de Propiedad Intelectual, en cuyos artículos 18 y 22 a 24 se desarrollan los procedimientos a seguir para esos dos supuestos de solicitud de autorización judicial de entrada para dos finalidades bien diferenciadas: en el artículo 18 se regula el procedimiento para la obtención de autorización judicial, a fin de poder recabar de los prestadores de servicios de intermediación los datos precisos para lograr la plena identificación del presunto responsable (sobre el cual existan indicios de que está vulnerando derechos de propiedad intelectual) mediante la localización del servicio de la sociedad de la información desde el que se comete la actuación ilegal, cuando el mismo no esté suficientemente identificado; mientras que en el artículo 23 se regula el procedimiento para la obtención de autorización judicial que permita exigir a los prestadores de servicios de intermediación de la sociedad de la información que adopten de inmediato las medidas necesarias a su alcance para suspender el servicio de la sociedad de la información sobre el que la Sección Segunda de la CPI ya ha dictado una resolución en la que, declarando acreditada la existencia de una vulneración de derechos de propiedad intelectual por el responsable del servicio de la sociedad de la información, le ordena al mismo la interrupción de la prestación del servicio o la retirada de contenidos, cuando la resolución no hubiera sido cumplida voluntariamente en el plazo de 24 horas desde su notificación por el responsable de ese servicio cuya actuación se ha declarado ilegal.

A estos efectos, es importante precisar que, de acuerdo con el Anexo de $D \ell^{-}$ finiciones de la Ley 34/2002, de 11 de julio, de servicios de la sociedad de la información y de comercio electrónico, se entiende por "Servicio de intermediación" aquél servicio de la sociedad de la información por el que se facilita la prestación o utilización de otros servicios de la sociedad de la información o el acceso a la información. De modo que son servicios de intermediación la provisión de servicios de acceso a Internet, la transmisión de datos por redes de telecomunicaciones, la realización de copia temporal de las páginas de Internet solicitadas por los usuarios, el alojamiento en los propios servidores de datos, aplicaciones 
o servicios suministrados por otros y la provisión de instrumentos de búsqueda, acceso y recopilación de datos o de enlaces a otros sitios de Internet.

Por lo que respecta al procedimiento para la obtención de la autorización judicial previa imprescindible para poder requerir a los prestadores de servicios de intermediación de la sociedad de la información la cesión de los datos que permitan la identificación del presunto responsable del servicio de la sociedad de la información que está realizando la conducta sobre la que existen indicios de una posible vulneración de derechos de propiedad intelectual para que pueda serle notificado el inicio del procedimiento empleándose en su caso los boletines oficiales existentes o portales de notificación creados a tales efectos, el artículo 122 bis.1 LJCA y el artículo 18 del Real Decreto 1889/2011 establecen las siguientes prescripciones:

- El procedimiento se iniciará con la solicitud a los Juzgados Centrales de lo Contencioso-Administrativo por parte de los órganos competentes (actualmente lo es la Sección Segunda de la Comisión de Propiedad Intelectual) en la que deberán exponerse necesariamente las razones que justifican la petición acompañada de los documentos y ficheros acreditativos que sean procedentes a estos efectos. Aún en el caso de que la CPI haya recibido varias denuncias o solicitudes de inicio del procedimiento contra un mismo servicio de la sociedad de la información, cuando las mismas tengan su razón de ser en una misma actividad vulneradora, la citada Sección Segunda de la CPI remitirá una única solicitud de autorización judicial.

- Recibida la solicitud, en el plazo máximo de las 24 horas siguientes a la petición el Juzgado Central de lo Contencioso-Administrativo al que haya correspondido su conocimiento dictará Auto autorizando o denegando la solicitud efectuada. Dentro de ese plazo de 24 horas, el Juzgado deberá, además, dar previa audiencia al Ministerio Fiscal.

Obviamente la autorización judicial habrá de concederse si en la solicitud formulada aparecen efectivamente justificadas la razones que imponen la necesidad de la autorización judicial y así queda debidamente probado con la documental que deberá acompañarse con la solicitud. En caso de que, por el contrario, con la solicitud y documentos acompañados no resulte acreditada la necesidad de esta autorización judicial, la misma deberá denegarse por el Magistrado-Juez, como ocurriría, por ejemplo, en el caso de que en el procedimiento instruido por la Sección 
Segunda de la Comisión de Propiedad Intelectual constase ya identificado el responsable del servicio de la Sociedad de la Información presuntamente vulnerador de derechos de propiedad intelectual. No obstante, el apartado 1 del artículo 122 bis establece un específico supuesto en el que esta autorización judicial deberá ser denegada, concretamente en el caso de que resulte afectado el artículo 18, apartados 1 y 3 , de nuestra Carta Magna que, recordemos, garantizan el derecho al honor, a la intimidad personal y familiar y a la propia imagen y el secreto de las comunicaciones, respectivamente.

- Tras dictarse el Auto, si el mismo concede la autorización judicial para la localización del responsable del servicio de la sociedad de la información, la Sección Segunda de la CPI trasladará el contenido del mismo al prestador del servicio de intermediación de la sociedad de la información requiriéndole, en su caso, para que aporte de forma inmediata en un plazo máximo de 48 horas desde la recepción del requerimiento los datos que permitan la inequívoca identificación del responsable mediante la localización del servicio de la sociedad de la información contra el que se dirige el procedimiento. Si, por el contrario, el Auto judicial denegara la autorización solicitada, la CPI estará igualmente obligada a dar traslado del mismo al prestador del servicio de intermediación de la sociedad de la información.

Por lo que se refiere al procedimiento para la obtención de la autorización judicial necesaria para el cumplimiento de la resolución de la Sección Segunda de la Comisión de Propiedad Intelectual que declara la existencia de una vulneración de derechos de propiedad intelectual por el responsable del servicio de la sociedad de la información, el mismo se desarrollará por los siguientes trámites, de acuerdo con lo que disponen el apartado 2 del artículo 122 bis LJCA y los artículos 22 a 24 del Real Decreto 1889/2011:

- El artículo 22 del Real Decreto 1889/2011 exige que en la misma resolución en que la CPI declara acreditada la existencia de una vulneración de derechos de propiedad intelectual por el responsable del servicio de la sociedad de la información objeto del procedimiento, ordene al referido responsable la retirada de los contenidos que vulneren derechos de propiedad intelectual o la interrupción de la prestación del servicio de la sociedad de la información que vulnere los citados derechos objeto del procedimiento, y que, asimismo, incluya un requerimiento dirigido a los servicios de intermediación de la sociedad de la información para que, 
en el caso de que el responsable del servicio de la sociedad de la información no cumpla dentro del plazo de 24 horas la orden de retirada de contenidos o de interrupción de la prestación decretada en la resolución, tales servicios de intermediación procedan a la suspensión de sus actividades de intermediación con el servicio de la sociedad de la información objeto de la resolución para conseguir el eficaz cumplimiento de la resolución. Esta resolución, además de notificársele al responsable del servicio infractor, deberá serle notificada también al correspondiente prestador de servicios de intermediación de la sociedad de la información.

- Si el responsable del servicio de la sociedad de la información no cumpliese voluntariamente lo exigido en esa resolución en el plazo de 24 horas desde su notificación, la Sección Segunda de la CPI solicitará del Juzgado Central de lo Contencioso-Administrativo competente la autorización para la ejecución forzosa de lo ordenado, justificando debidamente la posible afectación a los derechos y libertades garantizados en el artículo 20 de la Constitución ${ }^{27}$, de forma que resulte convincentemente razonado que las medidas ordenadas son objetivas, proporcionadas y no discriminatorias.

- En el plazo improrrogable de dos días siguientes a la solicitud, el Juzgado Central de lo Contencioso-Administrativo al que le haya correspondido, deberá convocar a una audiencia al representante legal de la Administración, al Ministerio Fiscal y a los titulares de los derechos y libertades afectados o persona que éstos designen como representante para asegurar la imprescindible contradicción, debiendo el Juzgado oír en esa comparecencia a todos los personados. En la resolución judicial que convoca a las partes a la audiencia, deberá ponérseles de manifiesto el expediente.

\footnotetext{
${ }^{27} \mathrm{El}$ artículo 20 de la Constitución Española se inserta sistemáticamente en la Sección I. DE LOS DERECHOS FUNDAMENTALES Y DE LAS LIBERTADES PÚBLICAS del Capítulo II. DERECHOS Y LIBERTADES de su TÍTULO I. DE LOS DERECHOS $Y$ DEBERES FUNDAMENTALES, y en el mismo se reconocen y protegen los derechos a expresar y difundir libremente los pensamientos, ideas y opiniones mediante la palabra, el escrito o cualquier otro medio de reproducción; a la producción y creación literaria, artística, científica y técnica; a la libertad de cátedra; y a comunicar o recibir libremente información veraz por cualquier medio de difusión. Si bien el precepto en su apartado 4 establece estas libertades tienen su límite en el respeto a los derechos reconocidos en este Título, en los preceptos de las Leyes que lo desarrollan y, especialmente, en el derecho al honor, a la intimidad, a la propia imagen y a la protección de la juventud y de la infancia.
} 
- Una vez celebrada la audiencia, el Magistrado-Juez tendrá que resolver en el plazo improrrogable de dos días mediante Auto, autorizando o denegando la ejecución forzosa de la medida.

- Tan pronto como la Sección Segunda de la CPI reciba ese Auto, tanto si concede como si deniega la autorización, la misma deberá notificárselo a la parte que haya iniciado el procedimiento, al responsable del servicio de la sociedad de la información vulnerador y a los prestadores de los servicios de intermediación de la sociedad de la información cuya colaboración sea necesaria. La notificación a estos últimos se realizará preferentemente por medios electrónicos.

- Los prestadores de los servicios de intermediación estarán obligados a dar cumplimiento a la suspensión decretada por la CPI y autorizada por el Juzgado Central de lo Contencioso-Administrativo competente en el plazo de las 72 horas siguientes a la notificación del Auto.

- La suspensión del servicio de intermediación cesará cuando se acredite ante la Sección Segunda el restablecimiento de la legalidad por parte del servicio de la sociedad de la información o, en todo caso, una vez transcurrido un año desde la ejecución de la medida, de acuerdo con lo dispuesto en el artículo 24.4 del Real Decreto 1889/2011.

Tanto el Auto que conceda/deniegue la autorización judicial previa para poder requerir a los prestadores de servicios de intermediación de la sociedad de la información la cesión de los datos que permitan la identificación del presunto responsable del servicio de la sociedad de la información indiciariamente vulnerador de derechos de propiedad intelectual como el Auto que conceda/deniegue la autorización judicial previa a la ejecución de las medidas subsidiarias de suspensión de los servicios de intermediación para cumplimiento de la resolución de interrupción de la prestación de servicios de la sociedad de la información o de retirada de contenidos que lesionen la propiedad intelectual, serán susceptibles de recurso de apelación, en un solo efecto, ante la Sala de lo Contencioso-Administrativo de la Audiencia Nacional, de conformidad con lo dispuesto en los artículos 11.2 y 80.1.d) LJCA, tras la modificación introducida en este último precepto por la Disposición Final CuadragésimaTercera de la Ley 2/2011, de 4 de marzo, de Economía Sostenible. 


\section{GONCLUSIONES}

De todo lo hasta aquí expuesto, cabe extraer las siguientes conclusiones:

1. La constitucionalidad y vinculación al principio de eficacia del privilegio de autotutela ejecutiva atribuido por nuestro ordenamiento a la Administración ha sido expresamente sancionada por nuestro Tribunal Constitucional, encontrando su fundamento en el artículo 103 CE que reconoce como uno de los principios a los que la Administración Pública ha de atenerse el de eficacia "con sometimiento pleno a la Ley y al Derecho", lo que supone una remisión a la decisión del legislador ordinario respecto de aquellas normas, medios e instrumentos en que se concrete la consagración de la eficacia, y, entre ellas, no cabe duda de que se encuentra la potestad de autotutela ejecutiva o de autoejecución susceptible de ejercitarse por cualquier Administración Pública, regulada actualmente con carácter general en el artículo 95 LRJPAC que dispone que las Administraciones Públicas, a través de sus órganos competentes, podrán proceder, previo apercibimiento, a la ejecución forzosa de los actos administrativos, encontrándose entre los medios de ejecución forzosa previstos en los artículos 96 y ss. de la misma norma la ejecución subsidiaria, cuando se trate de actos que puedan ser realizados por sujeto distinto del obligado por no ser personalísimos.

Aún en aquellos casos en que un determinado acto hubiese sido objeto de un recurso contencioso-administrativo en el que hubiere recaído una sentencia que haya alcanzado firmeza, llegado el momento de su ejecución forzosa es manifiesto que no se trata de ejecutar una sentencia firme, sino de ejecutar un acto administrativo, por más que el mismo haya sido confirmado judicialmente, por lo que la competente para su ejecución forzosa es la Administración Pública que lo dictó y no el Juzgado o Tribunal de la Jurisdicción Contencioso-Administrativa que desestimó la demanda entablada contra el concreto acto que se trata de ejecutar de modo forzoso. En otras palabras, la sentencia firme confirmatoria del acto administrativo no constituye fundamento para la acción ejecutiva prevista en los artículos 517 y ss. LEG.

2. Resulta frecuente que para la ejecución forzosa de los actos administrativos sea precisa la entrada en uno o varios domicilios, como única forma de llevar aquélla a cabo, en cuyo caso el artículo 96.3 LRJPAC exige que medie, con carácter previo al inicio de la ejecución forzosa, el consentimiento voluntario de los titulares de los domicilios a los que ha 
de accederse, o, en su defecto, la oportuna autorización judicial de entrada. Se trata de una exigencia impuesta por el artículo 18.2 Constitución Española para garantizar que sea un órgano judicial el que aprecie o contraste que cualquier afección del derecho fundamental a la inviolabilidad del domicilio consagrado en el propio artículo $18 \mathrm{CE}$, apartado primero, aparece totalmente justificada y que resulta la mínima imprescindible requerida para la ejecución forzosa del concreto acto administrativo. De modo que, en ausencia de consentimiento voluntario, la Administración Pública autora del acto que se pretende ejecutar de forma subsidiaria deberá interesar el otorgamiento de autorización judicial de entrada.

3. Superada ya la clásica polémica acerca de si eran los órganos de la Jurisdicción Penal o, por el contrario, de la Contencioso-Administrativa los competentes para conocer y resolver las solicitudes de autorizaciones judiciales de entrada cuando las mismas se formulan para la ejecución forzosa de actos administrativos derivada del tenor del antiguo artículo 87.2 de la Ley Orgánica 6/1985, de 1 de julio, del Poder Fudicial, que fue suprimido por el artículo único de la Ley Orgánica 6/1998, de 13 de julio, de reforma de la Ley Orgánica del Poder Fudicial, y sentado, por tanto, en virtud de lo dispuesto en el actual artículo 8.6 LJCA, que los competentes son los órganos de la Jurisdicción Contencioso-Administrativa, el debate se plantea ahora en otros términos, la cuestión que debe dilucidarse es la determinación del específico órgano de la referida Jurisdicción Contenciosa que ostenta la competencia funcional para conocer de las solicitudes de autorizaciones judiciales de entrada que formulan las Administraciones Públicas para acceder al domicilio de los afectados al objeto de ejecutar de forma subsidiaria actos administrativos incumplidos previamente por los obligados que pueden ser ejecutados por otros sujetos distintos de los propios obligados por no ser actos personalísimos.

Si bien la casuística posible es variada, la solución es la misma en todos los supuestos, salvo en uno de ellos. El órgano judicial competente funcionalmente para conocer de autorizaciones judiciales de entrada interesadas por las AAPP para ejecutar forzosamente actos administrativos dictados por las mismas va a ser siempre, con una única excepción a la que después nos referiremos, el Juzgado de lo Contencioso-Administrativo a quien le haya sido atribuido el asunto de acuerdo con el turno de reparto, y ello, incluso, en el supuesto de que exista sentencia firme desestimatoria de la demanda o declaratoria de inadmisibilidad del recurso recaída en recurso contencioso-administrativo cuyo objeto haya sido 
el mismo acto administrativo que se proyecta ejecutar forzosamente, ya que, al haber alcanzado firmeza la sentencia, nos encontramos ante un procedimiento judicial concluso y archivado, y, consecuentemente, no cabe en ningún caso entender que la autorización judicial de entrada es un incidente de tal procedimiento contencioso.

La única excepción a la competencia del Juzgado de lo Contencioso-Administrativo al que por reparto le corresponda el asunto viene constituida por aquéllos casos en los que, al momento de la solicitud de autorización judicial de entrada, se esté aún sustanciando un procedimiento contencioso-administrativo en el que resulte impugnado precisamente el acto administrativo para el que se solicita la autorización judicial, casos en los que, excepcionalmente, el órgano competente para otorgar la autorización judicial de entrada para la ejecución forzosa del acto será el Juzgado de lo Contencioso-Administrativo que esté ya conociendo del recurso contencioso-administrativo que se encuentra pendente.

En cambio, como excepción a su vez de esa excepción, en el caso de que la impugnación del acto administrativo para cuya ejecución forzosa se interesa la autorización judicial de entrada se esté sustanciando, no ante un Juzgado de lo Contencioso-Administrativo, sino ante la Sala de lo Contencioso-Administrativo del correspondiente Tribunal Superior de Justicia, entonces la competencia funcional para conocer de la solicitud de autorización judicial de entrada debe, a nuestro juicio, corresponder nuevamente a un Juzgado de lo Contencioso-Administrativo, al que por reparto le sea asignado, y no a la propia Sala de lo Contencioso-Administrativo, ya que apreciamos que otra conclusión sobre este particular nos conduciría a una flagrante vulneración de lo dispuesto en el antes citado artículo 8.6 LJCA que atribuye indubitadamente de forma exclusiva a los Juzgados de lo Contencioso-Administrativo la competencia objetiva para conocer de las autorizaciones judiciales de entrada en domicilio y restantes lugares cuyo acceso requiera el consentimiento de su titular, siempre que ello proceda para la ejecución forzosa de actos de las Administraciones Públicas, precepto que, de acuerdo con lo dispuesto en el artículo 3.1 del Código Civil, debe ser interpretado en concordancia y coordinación con los artículos 13.c), 80.1.d) y 87.1 de la misma LJCA.

4. Sin embargo, las autorizaciones judiciales tanto para poder exigir a los prestadores de servicios de intermediación de la sociedad de la información la entrega de los datos que permitan la plena identificación de los responsables de servicios de la sociedad de la información presunta- 
mente vulneradores de derechos de propiedad intelectual como para la ejecución forzosa de los actos de interrupción de la prestación de servicios de la sociedad de la información o de retirada de contenidos que vulneren esos derechos de propiedad intelectual poseen un régimen competencial diferenciado del resto de autorizaciones judiciales para ejecución forzosa de actos administrativos por cuanto que el conocimiento de estas específicas solicitudes de autorización judicial para protección de derechos de propiedad intelectual se aparta de la regla general al venirle atribuido a los Juzgados Centrales de lo Contencioso-Administrativo. Ello altera también la competencia para resolver los recursos de apelación que se interpongan contra los Autos que concedan o denieguen las autorizaciones judiciales en estos casos específicos relacionados con la tutela de la propiedad intelectual, ya que los mismos deberán ser resueltos por la Sala de lo Contencioso-Administrativo de la Audiencia Nacional, mientras que en el resto de los casos la competencia para resolver los recursos de apelación está residenciada en la Sala de lo Contencioso-Administrativo de los Tribunales Superiores de Justicia de las respectivas Comunidades Autónomas.

5. La intervención judicial en las autorizaciones judiciales de entrada para la ejecución forzosa de actos administrativos es específica, preventiva y limitada, ya que el juez no interviene en estos casos para enjuiciar la legalidad del acto administrativo que se trata de ejecutar, sino para garantizar que la restricción que se va a producir del derecho constitucional a la inviolabilidad del domicilio con ocasión de la ejecución forzosa de un acto administrativo es inevitable y proporcionada para la realización de intereses o fines públicos ante los que ese derecho particular debe ceder. Pero no por ello debe entenderse que la intervención del Magistrado-Juez se reduce a un mero automatismo formal, sino que la función del mismo en estos supuestos se extiende, de una parte, a la comprobación de la concurrencia en cada caso de los presupuestos que la jurisprudencia constitucional ha definido como necesarios para que pueda otorgarse la autorización judicial de entrada, y, de otra, a establecer las imprescindibles cautelas ad hoc sobre el acto de la entrada, entre ellas, las referidas a los aspectos temporales, evitando con ello la discrecionalidad, y mucho más la arbitrariedad, de la Administración en la determinación de estos aspectos, o, un sacrificio excesivo o evitable del derecho constitucional a la inviolabilidad del domicilio.

6. Por otra parte, de forma desacertada a nuestro juicio, el legislador no ha articulado un procedimiento general para la tramitación y resolución de 
las solicitudes de autorizaciones judiciales de entrada para ejecución forzosa de actos administrativos, desaprovechando, además, los últimos cambios legislativos producidos para haber subsanado la inicial omisión.

Pese a esta ausencia de establecimiento del cauce procesal a través del cual tramitar esas peticiones, sí que es posible establecer un conjunto de reglas que deben respetarse en todo caso en su tramitación. Estas reglas preceptivas se refieren a la forma de iniciación del procedimiento, la audiencia a los interesados, la forma y contenido de la resolución judicial y a los recursos legalmente procedentes.

En particular, sobre la audiencia a los interesados conviene resaltar que, según nuestro criterio, con carácter general constituye un trámite esencial necesario, puesto que es indudable que ha de darse la oportunidad de formular alegaciones a quien es titular del domicilio en el que se pretende la entrada para la ejecución forzosa de un acto a cuyo fin se solicita autorización judicial, dada la intromisión que ello supone en su mayor reducto de intimidad, si bien esas alegaciones deben limitarse a poner de manifiesto la ausencia de uno o más de los presupuestos que, de acuerdo con la doctrina del Tribunal Constitucional, deben examinarse por el juez con ocasión de estas solicitudes de autorizaciones judiciales de entrada, sin que tales alegaciones puedan, en cambio, extenderse pretendiendo un enjuiciamiento del acto administrativo que se va a ejecutar de modo forzoso, ya que no es éste el objeto de la limitada intervención judicial que se produce cuando se solicita por la Administración una autorización judicial con la referida finalidad.

7. En cambio, el legislador en la reforma legislativa de 2011, a través de la llamada Ley Sinde, sí que ha introducido dos procedimientos específicos para la tramitación y resolución de las autorizaciones judiciales de entrada que se solicitan, bien para la exigencia de datos que permitan identificar a los responsables de servicios de la sociedad de la información presuntamente dañosos de derechos de propiedad intelectual, o bien para la ejecución forzosa de los actos de interrupción de la prestación de servicios de la sociedad de la información o de retirada de contenidos que vulneren la propiedad intelectual, una vez acordada tal ejecución forzosa por la Sección Segunda de la Comisión de Propiedad Intelectual.

En el primero de los casos en el procedimiento judicial, que se deberá de resolver en un perentorio plazo de 24 horas desde la solicitud, se habrá 
de otorgar audiencia exclusivamente al Ministerio Fiscal, en tanto que en el segundo de los referidos procedimiento judiciales, el dirigido a obtener la autorización para interrumpir la prestación o retirar contenidos, se contempla una tramitación también breve, aunque no tan sumarísima como en el caso anterior y, como cuestión destacable, la audiencia en este caso no se limitará al Ministerio Fiscal, sino que se extenderá también al representante legal de la Administración y a los titulares de los derechos y libertades afectados o persona que estos designen para representarles, que deberán ser convocados a un acto a presencia judicial en el que, con la debida contradicción, podrán formular sus respectivas alegaciones a favor o en contra del otorgamiento de la autorización judicial interesada. 